\title{
Article \\ Performance Analysis of the 50 MW Concentrating Solar Power Plant under Various Operation Conditions
}

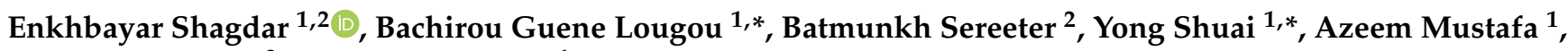 \\ Enkhjin Ganbold ${ }^{3}$ and Dongmei Han ${ }^{1}$ \\ 1 School of Energy Science and Engineering, Harbin Institute of Technology (HIT), Harbin 150001, China; \\ enkhbayar.sh@must.edu.mn (E.S.); azeem.mustafa6@gmail.com (A.M.); 17b902047@stu.hit.edu.cn (D.H.) \\ 2 School of Power Engineering, Mongolian University of Science and Technology (MUST), \\ Ulaanbaatar 14191, Mongolia; batmunkh_acad@must.edu.mn \\ 3 School of Mechanical and Power Engineering, Harbin University of Science and Technology (HUST), \\ Harbin 150001, China; enkhjin.g92@yahoo.com \\ * Correspondence: bachguelou@yahoo.fr (B.G.L.); shuaiyong@hit.edu.cn (Y.S.)
}

Citation: Shagdar, E.; Lougou, B.G.; Sereeter, B.; Shuai, Y.; Mustafa, A.; Ganbold, E.; Han, D. Performance Analysis of the $50 \mathrm{MW}$ Concentrating Solar Power Plant under Various Operation Conditions. Energies 2022, 15, 1367. https://doi.org/ $10.3390 /$ en15041367

Academic Editor: Jesús Polo

Received: 26 January 2022

Accepted: 8 February 2022

Published: 14 February 2022

Publisher's Note: MDPI stays neutral with regard to jurisdictional claims in published maps and institutional affiliations.

Copyright: (C) 2022 by the authors. Licensee MDPI, Basel, Switzerland. This article is an open access article distributed under the terms and conditions of the Creative Commons Attribution (CC BY) license (https:// creativecommons.org/licenses/by/ $4.0 /)$.

\begin{abstract}
Power generation using concentrating solar energy is a potential solution to provide clean, green, and sustainable power generation in the long term. The objective of this paper is to analyze the performance of a parabolic trough collector-based concentrating solar power (CSP) plant by selecting four different reference days (i.e., 22 March, 22 June, 22 September, and 22 December), representing four seasons in Mongolian climate conditions. Numerical simulation of the 50 MW CSP plant was performed, both at nominal and part-load conditions using the heat balance method considering variations of power load owing to the direct normal irradiation (DNI). The results revealed that the 50 MW CSP plant could operate well throughout the year, and it showed the highest value of operating performance for the 22 June due to the higher DNI and small solar incidence angle. The operating performance for the 22 March and 22 September is nearly similar. The lowest value of operating performance occurred on the 22 December. Moreover, the operating performance of the CSP plant in the part-load conditions was significantly reduced compared to the nominal load owing to the DNI fluctuation. This study also revealed that the CSP plant could significantly contribute to environmental protection and climate change mitigation.
\end{abstract}

Keywords: solar thermal power plant; parabolic trough collector; performance analysis; part-load conditions; IPSEpro software

\section{Introduction}

Nowadays, the world's population is growing unceasingly, and therefore the electricity demand is estimated to increase. It is the main reason for increasing greenhouse gas emissions. For instance, greenhouse gas emissions from electricity and heat production have contributed to the largest global greenhouse gas emissions in 2014, with a share of about 25\% [1]. To reduce greenhouse gas emissions, a large number of studies have been conducted related to the utilization of renewable energy for power generation purposes with minimum pollutants. Solar energy is the most abundant, sufficient, and cleanest available anywhere among renewable energy resources. According to the technology roadmaps of the CSP provided by the International Energy Agency (IEA) in 2010 [2], the CSP could supply $11.3 \%$ of global electricity by 2050 . In addition, the one-megawatt capacity of the CSP can avoid 1360 tons of $\mathrm{CO}_{2}$ emission compared to the coal-fired power plant [3].

Regarding the trend of power generation development, solar energy is undoubtedly the next generation of clean, green, and sustainable energy resource for power generation. Two main power generation methods use solar energy in power generation practice, such as solar photovoltaic (PV) [4] and CSP technology [5]. Moreover, solar chimney technology 
is one of the potential solutions for solar power generation [6,7]. Besides, another interesting method of solar power generation in the short and midterm is solar-assisted power generation, which is the hybridization of solar energy and fossil fuel-based conventional thermal power plants [8]. From the future perspective of dispatchability, energy storage, and system efficiency, CSP technology is superior to PV technology [2,3]. Nowadays, four different types of technically mature CSP technologies, such as parabolic trough collectors (PTC), linear Fresnel collectors (LFC), solar power tower (SPT), and parabolic dish (PD) systems, are used to generate electricity using solar energy via a thermodynamic principle [9]. Moreover, the high-temperature potential available in SPT and PD technologies can be used for fuel production via steam reforming and thermochemical approaches [10-12]. Among these CSP technologies, the PTC technology is the most developed and commonly practiced for power generation $[13,14]$.

In recent years, intensive studies on CSP plants have been investigated using different methods and technologies under various operation conditions $[5,15]$. Some researchers have studied the thermodynamic analysis of the CSP plant using first and second laws. Reddy et al. investigated energetic and exergetic analysis of the $50 \mathrm{MW}$ parabolic troughbased CSP plant for two different tropical locations to optimize the operating pressures of the Rankine cycle for the maximum efficiency of the system by considering a variety of condenser pressure concerning ambient temperature [16]. Desai et al. [17] performed the extensive energy and economic analysis of parabolic trough collector-based CSP plants to study effects of turbine inlet pressure and temperature, design radiation, plant capacity, and various modifications of Rankine cycle on overall efficiency, as well as levelized cost of electricity $(\mathrm{LCOE}=0.188 \$ / \mathrm{kWh})$.

Moreover, many studies have conducted detailed investigations on the performance analysis, techno-economic evaluation, and economic analysis of the CSP plants with various capacities using different numerical methods. Yuanjing et al. [18] achieved the performance analysis of the 30 MW CSP plant for performance improvement of SEGS VI trough solar power plant. Sultan et al. [19] examined the techno-economic competitiveness of the $50 \mathrm{MW}$ CSP plants under Kuwait climatic conditions considering solar multiple and the number of operation hours of thermal energy storage (TES). Wang et al. [20] conducted thermodynamic and economic analyses of the CSP plant with an air-cooled condenser, considering the effects of meteorological conditions, including DNI and ambient temperature. Praveen et al. [21] investigated performance analysis of the 100 MW CSP plant in two different sites of the Middle East Region to optimize the initial plant design by considering variations of the solar multiple (SM) and operation hours of TES. Shafiee et al. [22] demonstrated a life cost analysis model to support investment decision-making in CSP projects based on the net present value, internal rate of return and discounted payback period of the investment, and LCOE. Results show that the average LCOE is $0.16 \$ / \mathrm{kWh}$. Boukelia et al. [23] analyzed and compared the techno-economic and environmental potential of two different CSP plants in terms of both hourly and annual performances using an ANN-based approach. Ikhlef et al. [24] performed a techno-economic optimization of a $25 \mathrm{MW}$ parabolic trough power plant in Algeria by considering the solar multiple, fossil fill fraction of the backup system, and a full load of TES.

Besides, many studies related to the operation conditions of the CSP plant have been performed under different geographical locations with various climate conditions. Teleszewski et al. reported the analysis of the applicability of the parabolic trough CSP plants in the temperate climate locations. Results revealed that geographical location was strongly affected by the operating performance of the CSP plant [25]. Aqachmar et al. presented a detailed investigation of the Noor-I parabolic trough CSP plant located in Morocco [26]. Mohamed et al. studied the effects of plant site location on the performance of CSP plants with molten salt TES under three different locations in Egypt [27].

Furthermore, numerous studies have been conducted on the operation conditions of the solar field (SF), TES system, and power block (PB) to improve the operating performance of the CSP plant. Mokheimer et al. [28] analyzed the techno-economic performance of the 
PTC solar field in Dhahran, Saudi Arabia by considering average hourly, daily, monthly, and annually-averaged weather data. Wang et al. [29] examined the daily performance of PTCs in three different regions of China under different seasons, considering cosine effect, shadowing effect, end loss effect, and optical efficiency. González-Portillo et al. [30] performed the analytical optimization of the TES system for LCOE reduction in CSP plants considering the costs and efficiencies of the three main parts (SF, TES, and PB) of the CSP plant. Topel et al. [31] investigated performance improvement of the CSP plant by increasing steam turbine flexibility during start-up. Schenk et al. [32] developed the dynamic model to evaluate and optimize the transient behavior of PB in the CSP plant during normal, warm, and hot start-up operation modes. Gonzalez et al. performed a simulation of a solar steam generator in the CSP plant via machine learning using a complete year of data from a commercial CSP plant [33]. Salazar et al. performed analytic modeling of the energy flow in parabolic trough solar thermal power plants under low-latitude locations, considering the effect of solar field operation on the turbine power and efficiency [34].

As can be seen in previous studies, the performance analysis of the CSP plant located in warm climate conditions with higher DNI was mainly investigated under nominal load. Therefore, it is significantly important to investigate the performance of the CSP plant located in temperate climate conditions under part-load conditions. The novelty of this study lies in the following several aspects:

(1) Performance analysis of the 50 MW CSP plant is performed in the nominal and part-load conditions;

(2) Effect of power output on the operating performance of the power block is investigated considering the variation of power output caused by the variation of DNI;

(3) Effect of variation of DNI on the operating performance of the solar field is considered in the design-point condition;

(4) Effect of outlet temperature of the heat transfer fluid (HTF) on the operating parameters of the solar field is examined in the design-point condition;

(5) The aperture area of the solar field is optimized using a solar multiple considering the minimum LCOE;

(6) Effect of daily DNI on the operating performance of the solar field and CSP plant system is considered under four different reference days.

\section{Methods and Methodology}

From the literature review, it can be seen that the performance analysis of CSP plants has been performed using simulation tools including SAM: 2021-12-02 [35], IPSEpro7.0 [14], Epsilon15.0 [23], Transys18.0 [36], Matlab2019 [27], Modelica3.5 [37], and other relevant software utilizing the material and energy balance approach based on the thermodynamics' first and second laws. In this study, the IPSEpro software (CSP library) is used in the numerical simulation of the 50 MW CSP plant [38,39]. The numerical simulation of the 50 MW CSP plant consists of three subsystems: solar field, thermal energy storage, and power block. The $50 \mathrm{MW}$ CSP plant is modeled according to component models, subsystems, and complete systems, which are defined as the basic chemical and physical processes [40]. The solar irradiation model and solar position (geometrical) calculations are not presented in this study. The basic thermodynamic equations of component models used in the numerical simulation of the CSP plant are comprehensively discussed in the present study.

\subsection{Model of Solar Field Subsystem}

The model of the solar field subsystem consists of the following component models, including PTCs, HTF system, HTF pump, TES system, and oil-water heat-exchanger (steam generation and steam reheating system). The basic mass and heat balance of component models used in the solar field subsystem are provided as the following formulae [38,39,41]. Moreover, the simulation model of the 50 MW CSP plant was considered a limited factor of 
shadow argument, the end loss coefficient, cleanliness of mirrors, optical losses, as well as thermal losses.

\subsubsection{Parabolic Trough Collector}

PTC technology is widely used in the CSP plant due to its efficiency and simple operation condition. Mass and heat (the heat is added to the process) balance:

$$
\left\{\begin{array}{l}
m_{\mathrm{f}}=m_{\mathrm{d}} ; \\
h_{\mathrm{f}} \cdot m_{\mathrm{f}}+q_{\text {coll }}=h_{\mathrm{d}} \cdot m_{\mathrm{d}}
\end{array}\right.
$$

where $m_{\mathrm{f}}$ and $m_{\mathrm{d}}$ are mass flow rates of feed and drain stream $(\mathrm{kg} / \mathrm{s}) ; h_{\mathrm{f}}$ and $h_{\mathrm{d}}$ are enthalpies of feed and drain stream $(\mathrm{kJ} / \mathrm{kg}) ; q_{\text {coll }}$ is the heat absorbed in the collector by the $\mathrm{HTF},(\mathrm{kW})$.

Heat amount absorbed in the collector by the HTF:

$$
q_{\mathrm{coll}}=q_{\mathrm{DII}}-q_{\mathrm{loss}}
$$

where $q_{\mathrm{DII}}$ is the heat gain of the PTC from direct incident irradiation (DII) $(\mathrm{kW})$; $q_{\text {loss }}$ is the optical and thermal losses of the PTC, including thermal losses of a pipeline $(\mathrm{kW})$.

Direct incident irradiation:

$$
D I I=\eta_{\mathrm{opt}} \cdot \eta_{\mathrm{shad}} \cdot \eta_{\mathrm{endloss}} \cdot I A M \cdot \eta_{\text {clean }} \cdot D N I
$$

where $\eta_{\text {opt }}$ is the optical efficiency of a collector (for Eurotrough-150 collector: $\eta_{\mathrm{opt}}=0.75$ ); $\eta_{\text {shad }}$ is the limited factor of shadow argument $\left(\eta_{\text {shad }}=1.0\right) ; \eta_{\text {endloss }}$ is the end loss coefficient $\left(\eta_{\text {endloss }}=0.99\right) ;$ I $A M$ is the incident angle modifier (IAM) (for Eurotrough-150 collector: $I A M=\cos (\theta \cdot 0.017453)-0.000525 \cdot \theta-0.0000286 \theta^{2} ; \theta$ is the incidence angle); $\eta_{\text {clean }}$ is the cleanliness of mirrors $\left(\eta_{\text {clean }}=0.97\right) ; D N I$ is direct normal irradiance $\left(\mathrm{W} / \mathrm{m}^{2}\right)$;

Apparent aperture area of one parabolic trough collector unit, $\left(\mathrm{m}^{2}\right)$ :

$$
A_{\text {coll }}=\eta_{\text {aperture }} \cdot A_{\text {collo }}
$$

where $\eta_{\text {aperture }}$ is the aperture factor representing defocusing of mirrors (for all mirrors aimed at target: $\eta_{\text {aperture }}=1$, for all mirrors defocused: $\left.\eta_{\text {aperture }}=0\right) ; A_{\text {collo }}$ is the physical aperture area of one parabolic trough unit (for Eurotrough-150 collector: $A_{\text {collo }}=817.5 \mathrm{~m}^{2}$ ).

Aperture area of the solar field, $\left(\mathrm{m}^{2}\right)$ :

$$
A_{\mathrm{SF}}=A_{\mathrm{PTC}} \cdot N_{\mathrm{coll}} \cdot N_{\text {loops }}
$$

where $N_{\text {coll }}$ is the number of PTC per loop; $N_{\text {loops }}$ is the number of parallel subsystems represented by the collector loop.

The heat gains of the PTC from direct incident irradiation:

$$
q_{\mathrm{coll}}=D I I \cdot A_{\mathrm{coll}}
$$

The thermal efficiency of the PTC solar field can be expressed by instantaneous value for actual feed and drain conditions. The thermal efficiency of the solar field can be defined as the following equation:

$$
\eta_{\mathrm{SF}}=\frac{m_{\mathrm{HTF}} \cdot\left(h_{\mathrm{HTF}}^{\mathrm{out}}-h_{\mathrm{HTF}}^{\text {in }}\right)}{D N I \cdot A_{\mathrm{SF}}}
$$

where $m_{\mathrm{HTF}}$ is the mass flow rate of the $\operatorname{HTF}(\mathrm{kg} / \mathrm{s}) ; h_{\mathrm{HTF}}^{\text {out }}, h_{\mathrm{HTF}}^{\text {in }}$ are the enthalpies of the $\mathrm{HTF}$ at outlet and inlet of the solar field $(\mathrm{kJ} / \mathrm{kg})$. 
Thermal losses of parabolic trough collector:

$$
q_{\text {loss.PTC }}=A_{\mathrm{PTC}} \cdot\left[\left(a+c \cdot v_{\text {wind }}\right) \cdot\left(t_{\mathrm{abs}}-t_{\mathrm{amb}}\right)+\varepsilon \cdot b \cdot\left(t_{\mathrm{abs}}^{4}-t_{\mathrm{sky}}^{4}\right)\right]
$$

where parameters $a, b$, and $c$ are empiric constant [42] $\left(a=0.01982 \mathrm{~W} / \mathrm{K} \cdot \mathrm{m}^{2}, b=0.00000000202\right.$ $\left.\mathrm{W} / \mathrm{K}^{4} \cdot \mathrm{m}^{2}, c=0.006612 \mathrm{~J} / \mathrm{K} \cdot \mathrm{m}^{3}\right) ; v_{\text {wind }}$ is the wind velocity $(\mathrm{m} / \mathrm{s}) ; t_{\mathrm{abs}}$ is the absorber tube outer wall temperature $(\mathrm{K}) ; t_{\mathrm{amb}}$ is the ambient temperature $(\mathrm{K}) ; t_{\mathrm{sky}}$ is the sky temperature $(\mathrm{K}) ; \varepsilon$ is the absorber tube emissivity $\left(\varepsilon=0.0042 \cdot t_{\mathrm{abs}}-0.0995\right)$.

Thermal losses of pipeline [38]:

$$
q_{\text {loss.pipe }}=U \cdot 3.14159 \cdot d_{0} \cdot L \cdot\left(\frac{\left(t_{f}+t_{d}\right)}{2}-t_{\mathrm{amb}}\right)
$$

where $U$ is the overall heat transfer coefficient $\left(\mathrm{W} / \mathrm{m}^{2} \cdot \mathrm{K}\right) ; d_{0}$ is the outer diameter of insulated connection pipeline $(\mathrm{m}) ; \mathrm{L}$ is the actual length of connection pipe $(\mathrm{m})$.

In this study, we have selected the EuroTrough-150 collectors. The main technical specifications of the EuroTrough-150 collector [43] are summarized in Table 1.

Table 1. Main technical specifications of EuroTrough-150 collector.

\begin{tabular}{ccc}
\hline Parameters & Units & Values \\
\hline Name of collector & - & ET-150 \\
Collector length & $\mathrm{m}$ & 150 \\
Aperture width of parabolic trough & $\mathrm{m}$ & 5.77 \\
Focal length & $\mathrm{m}$ & 1.71 \\
The inner diameter of the absorber pipe & $\mathrm{m}$ & 0.059 \\
The roughness of the inner wall of the absorber pipe & $\mathrm{m}$ & 0.0001 \\
Distance between collector rows & $\mathrm{m}$ & 17.31 \\
Optical efficiency & $\%$ & 75.0 \\
Mirror reflectivity & $\%$ & 94.0 \\
\hline
\end{tabular}

\subsubsection{Oil-Water/Steam Heat-Exchanger}

Oil-water heat exchanger for transfer from heat transfer fluid on the hot side to cooling fluid (feedwater and steam) on the cold side.

Mass and heat balance of heat-exchanger on the hot side:

$$
\left\{\begin{array}{l}
m_{\mathrm{f}}^{\mathrm{h}}=m_{\mathrm{d}}^{\mathrm{h}} ; \\
m_{\mathrm{f}}^{\mathrm{h}} \cdot\left(h_{\mathrm{f}}^{\mathrm{h}}-h_{\mathrm{d}}^{\mathrm{h}}\right) \cdot\left(1.0-q_{\text {loss }} / 100\right)=q_{\text {trans }}
\end{array}\right.
$$

Mass and heat balance of heat-exchanger on the cold side:

$$
\left\{\begin{array}{l}
m_{\mathrm{f}}^{\mathrm{c}}=m_{\mathrm{d}}^{\mathrm{c}} ; \\
m_{\mathrm{f}}^{\mathrm{c}} \cdot\left(h_{\mathrm{d}}^{\mathrm{c}}-h_{\mathrm{f}}^{\mathrm{c}}\right)=q_{\text {trans }}
\end{array}\right.
$$

where $m_{\mathrm{f}}^{\mathrm{h}}$ and $m_{\mathrm{d}}^{\mathrm{h}}$ are mass flow rates of feed and drain stream on the hot side $(\mathrm{kg} / \mathrm{s}) ; h_{\mathrm{f}}^{\mathrm{h}}$ and $h_{\mathrm{d}}^{\mathrm{h}}$ are enthalpies of feed and drain stream on the hot side $(\mathrm{kJ} / \mathrm{kg}) ; q_{\text {loss }}$ is the thermal loss of oil-water heat exchanger $(\mathrm{kW}) ; q_{\text {trans }}$ is the transferred heat $(\mathrm{kW}) ; m_{\mathrm{f}}^{\mathrm{c}}$ and $m_{\mathrm{d}}^{\mathrm{c}}$ are mass flow rates of feed and drain stream on the cold side $(\mathrm{kg} / \mathrm{s}) ; h_{\mathrm{f}}^{\mathrm{c}}$ and $h_{\mathrm{d}}^{\mathrm{c}}$ are enthalpies of feed and drain stream on the cold side $(\mathrm{kJ} / \mathrm{kg})$.

Transferred heat into the working fluid:

$$
q_{\text {trans }}=U \cdot A_{\mathrm{OW}} \cdot t_{\mathrm{MTD}}
$$

where $A_{\mathrm{OW}}$ is the heat transfer area of an oil-water heat exchanger $\left(\mathrm{m}^{2}\right) ; t_{\mathrm{MTD}}$ is the mean temperature difference $(\mathrm{K})$. 


\subsubsection{Heat Transfer Fluid}

Heat transfer fluid plays an important role in CSP applications. In this study, Therminol VP-1 is chosen as the HTF for obtaining high temperatures, since it has a boiling point around $257^{\circ} \mathrm{C}$ at a pressure of 1013 mbar. Therminol VP-1 is employed up to $400{ }^{\circ} \mathrm{C}$. Therminol VP1 is a synthetic mixture oil, which is widely used for CSP applications. Thermo-physical properties correlation as a function of temperature for Therminol VP1 [44]:

$$
\left\{\begin{array}{l}
c_{p}=2.82 \cdot T+716 \\
\lambda=1.73 \times 10^{-7} \cdot T^{2}+7.62 \times 10^{-6} \cdot T+0.14 \\
\rho=-7.61 \times 10^{-4} \cdot T^{2}-2.24 \times 10^{-1} \cdot T+1191 \\
\mu=\left(-23 \times 10^{-5} \cdot T^{3}+5.61 \times 10-3 \cdot T^{2}-19.89 \cdot T+1822\right)^{-1}
\end{array}\right.
$$

\subsection{Model of TES Subsystem}

In this study, the proposed 50 MW CSP plant was designed to install an indirect molten salt TES system. The TES system is composed of two molten salt storage tanks, which are stored thermal power absorbed by the Therminol VP-1 from the solar field. In order to avoid oversizing the thermal energy backup, the TES system was selected with a six hours' full operation load. The TES system can stabilize the fluctuation of DNI and improve the stable and reliable operation condition of the CSP plant in part-load conditions. When DNI grows more than the design-point value, the HTF will be stored in the TES system in the thermal energy form so that the stored thermal energy can be used for power generation during the available time. The TES includes two types of tanks, named hot and cold. The mass and thermal balance in the hot and cold tanks are similar formulae [45].

Mass and heat balance of the hot tank (HT):

$$
\begin{aligned}
& m_{\mathrm{HT}}=m_{\mathrm{res}}+\left(m_{\mathrm{f}}-m_{\mathrm{d}}\right) \cdot \Delta \tau ; \\
& Q_{\mathrm{HT}}=Q_{\mathrm{res}}+\left(q_{\mathrm{f}}-q_{\mathrm{d}}-q_{\operatorname{loss}(\mathrm{HT})}\right) \cdot \Delta \tau
\end{aligned}
$$

where $m_{\mathrm{HT}}$ is the mass flow rate of HTF in the HT $(\mathrm{kg} / \mathrm{s}) ; m_{\text {res }}$ is the initial mass flow rate of HTF in the HT $(\mathrm{kg} / \mathrm{s}) ; m_{\mathrm{f}}$ and $m_{\mathrm{d}}$ are the inlet and outlet mass flow rates of HTF of the $\mathrm{HT}$, respectively $(\mathrm{kg} / \mathrm{s}) ; \Delta \tau$ is the time interval (s); $Q_{\mathrm{HT}}$ is the thermal energy stored in the HT (kW); $Q_{\text {res }}$ is the initial energy stored in the HT $(\mathrm{kW}) ; q_{\mathrm{f}}$ and $q_{\mathrm{d}}$ are the thermal power inlet and outlet of the HT, respectively $(\mathrm{kW})$.

The thermal energy loss of the hot tank:

$$
q_{\operatorname{loss}(\mathrm{HT})}=U \cdot A_{\mathrm{HT}} \cdot\left(t_{\mathrm{HT}}-t_{\mathrm{amb}}\right)
$$

where $A_{\mathrm{HT}}$ is the heat transfer area of the HT $\left(\mathrm{m}^{2}\right) ; t_{\mathrm{HT}}$ is the temperature of HTF in the HT $(\mathrm{K})$.

\subsection{Model of Power Block Subsystem}

The model of the power block subsystem consists of a steam turbine, electric generator, condenser, low-pressure preheaters, deaerator, high-pressure preheaters, pumps, and electric motors [46]. The following formulae provide the basic mass and heat balance of component models used in the model of power block.

\subsubsection{Model of the Steam Turbine}

The component model of the steam turbine is modeled as the single pressure stage or the pressure stage group. Mass and heat balance:

$$
\left\{\begin{array}{l}
m_{\mathrm{f}}-m_{\mathrm{d}}=0.0 \\
h_{\mathrm{f}}-h_{\mathrm{d}}=\Delta h_{\mathrm{s}} \cdot \eta_{\mathrm{s}}
\end{array}\right.
$$

Power production:

$$
\left(h_{\mathrm{f}}-h_{\mathrm{d}}\right) \cdot \eta_{\mathrm{m}} \cdot m_{\mathrm{f}}-W_{\text {out }}=0.0
$$


where $\Delta h_{\mathrm{s}}$ is the isentropic enthalpy difference $(\mathrm{kJ} / \mathrm{kg}) ; \eta_{\mathrm{s}}$ is the isentropic efficiency $(\%)$; $\eta_{\mathrm{m}}$ is the mechanical efficiency (\%); $W_{\text {out }}$ is the power production $(\mathrm{kW})$.

In the CSP plant, the steam turbine works in part-load conditions due to the variation of solar irradiation. Steam parameters of the steam turbine in the part-load conditions can be defined by the Stodola-Flugel equation:

$$
\frac{m \prime_{i}}{m_{i}}=\sqrt{\frac{p_{i}^{\prime 2}-p_{i+1}^{\prime 2}}{p_{i}^{2}-p_{i+1}^{2}}} \sqrt{\frac{T_{i}}{T \prime_{i}}}
$$

where $m_{i}$ and $m i_{i}$ are the mass flows of steam inlet and outlet of turbine pressure stage at off-design regime $(\mathrm{kg} / \mathrm{s}) ; p_{i}$ and $p_{i+1}$ are the steam pressures of inlet and outlet of turbine pressure stage at design regime (bar); $p \prime_{i}$ and $p \prime_{i+1}$ are the steam pressures of inlet and outlet of turbine pressure stage at off-design regime (bar); $T_{i}$ and $T \prime_{i}$ are the steam temperatures of inlet turbine pressure stage at design and off-design regime (K).

\subsubsection{Model of the Electric Generator}

The purpose of an electric generator is to convert mechanical energy (shaft power) into electrical energy (power output). The power output of the electric generator:

$$
W_{\text {out }}-\eta_{\mathrm{el}} \cdot \eta_{\mathrm{m}} \cdot W_{\text {shaft }}=0.0
$$

where $W_{\text {out }}$ is the electrical power output $(\mathrm{kW}) ; \eta_{\mathrm{el}}$ is the electrical efficiency $(\%) ; W_{\text {shaft }}$ is the shaft power $(\mathrm{kW})$.

\subsubsection{Model of Motor}

The purpose of an electric motor is to convert electrical energy into mechanical energy. Electrical power input of motor:

$$
W_{\mathrm{m}}=\frac{W_{\text {shaft }}}{\eta_{\mathrm{el}} \cdot \eta_{\mathrm{m}}}
$$

where $W_{\text {shaft }}$ is the shaft power of motor $(\mathrm{kW})$; $\eta_{\mathrm{el}}$ electrical efficiency of motor $(\%) ; \eta_{\mathrm{m}}$ is the mechanical efficiency of motor $(\%)$.

\subsubsection{Model of Pump}

The purpose of the pump is to transport fluids by the conversion of rotational kinetic energy to the hydrodynamic energy of the fluid flow using an electric motor. Shaft power of the pump:

$$
W_{\text {shaft }}=\frac{m_{\mathrm{f}} \cdot\left(h_{\mathrm{d}}-h_{\mathrm{f}}\right)}{\eta_{\mathrm{m}}}
$$

where $m_{\mathrm{f}}$ is the mass flow rate of the feed stream $(\mathrm{kg} / \mathrm{s}) ; h_{\mathrm{d}}$ and $h_{\mathrm{f}}$ are the enthalpies of drain and feed streams $(\mathrm{kJ} / \mathrm{kg}) ; \eta_{\mathrm{m}}$ is the mechanical efficiency of the pump.

\subsubsection{Model of Heat Exchangers}

The high-pressure preheaters, low-pressure preheaters, and steam condenser are the surface type of heat exchangers.

Mass and heat balance of feedwater preheaters at the hot and cold side:

$$
\begin{aligned}
& \left\{\begin{array}{l}
m_{\mathrm{f}}^{\mathrm{h}}=m_{\mathrm{d}}^{\mathrm{h}} ; \\
m_{\mathrm{f}}^{\mathrm{h}} \cdot\left(h_{\mathrm{f}}^{\mathrm{h}}-h_{\mathrm{d}}^{\mathrm{h}}\right)-q_{\text {trans }}=0.0
\end{array}\right. \\
& \left\{\begin{array}{l}
m_{\mathrm{f}}^{\mathrm{c}}=m_{\mathrm{d}}^{\mathrm{c}} ; \\
m_{\mathrm{f}}^{\mathrm{c}} \cdot\left(h_{\mathrm{f}}^{\mathrm{c}}-h_{\mathrm{d}}^{\mathrm{c}}\right)+q_{\text {trans }}=0.0
\end{array}\right.
\end{aligned}
$$


Mass and heat balance of steam condenser at the hot and cold side:

$$
\begin{aligned}
& \left\{\begin{array}{l}
m_{\mathrm{f}}^{\mathrm{h}}+m_{\mathrm{f} . \mathrm{rc}}=m_{\mathrm{d}}^{\mathrm{h}} ; \\
m_{\mathrm{f}}^{\mathrm{h}} \cdot h_{\mathrm{f}}^{\mathrm{h}}+m_{\mathrm{f} . \mathrm{rc}} \cdot h_{\mathrm{f} . \mathrm{rc}}-m_{\mathrm{d}}^{\mathrm{h}} \cdot h_{\mathrm{d}}^{\mathrm{h}}=q_{\text {trans }}
\end{array}\right. \\
& \left\{\begin{array}{l}
m_{\mathrm{f}}^{\mathrm{c}}=m_{\mathrm{d}}^{\mathrm{c}} ; \\
m_{\mathrm{f}}^{\mathrm{c}} \cdot h_{\mathrm{f}}^{\mathrm{c}}-m_{\mathrm{d}}^{\mathrm{c}} \cdot h_{\mathrm{d}}^{\mathrm{c}}+q_{\text {trans }}=0.0
\end{array}\right.
\end{aligned}
$$

Deaerator is a mixed type of heat exchanger, which is employed for preheating and deaerating the feedwater. Mass and heat balance of deaerator:

$$
\left\{\begin{array}{l}
m_{\mathrm{f}}^{\mathrm{c}}+m_{\mathrm{f}}^{\mathrm{h}}+m_{\mathrm{f} . \mathrm{rc}}=m_{\mathrm{d}} ; \\
m_{\mathrm{f}}^{\mathrm{c}} \cdot h_{\mathrm{f}}^{\mathrm{c}}+m_{\mathrm{f}}^{\mathrm{h}} \cdot h_{\mathrm{f}}^{\mathrm{c}}+m_{\mathrm{f} . \mathrm{rc}} \cdot h_{\mathrm{f} . \mathrm{rc}}=m_{\mathrm{d}} \cdot h_{\mathrm{d}}
\end{array}\right.
$$

where $m_{\mathrm{f}}^{\mathrm{h}}, m_{\mathrm{d}}^{\mathrm{h}}, m_{\mathrm{f} . \mathrm{rc}}$ are mass flow rates of hot streams for feed, drain, and recycle $(\mathrm{kg} / \mathrm{s})$; $m_{\mathrm{f}}^{\mathrm{c}}, m_{\mathrm{d}}^{\mathrm{c}}$ are mass flow rates of cold streams for feed, drain, and recycle $(\mathrm{kg} / \mathrm{s}) ; h_{\mathrm{f}}^{\mathrm{h}}, h_{\mathrm{d}}^{\mathrm{h}}, h_{\mathrm{f} . \mathrm{rc}}$ are the enthalpies of hot streams $(\mathrm{kJ} / \mathrm{kg}) ; h_{\mathrm{f}}^{\mathrm{c}}, h_{\mathrm{d}}^{\mathrm{c}}$ are the enthalpies of cold streams $(\mathrm{kJ} / \mathrm{kg})$; $q_{\text {trans }}$ is the transferred heat $(\mathrm{kW})$.

\subsection{Performance Characteristics of the CSP Plant}

The aperture area of the solar field is one of the key parameters for designing the CSP plant, representing the major investment cost of the CSP plant. The optimal aperture area of the solar field is characterized by a solar multiple, which can be determined as the ratio between the solar thermal powers received from the solar field in the design point to the thermal power required in the power block in the nominal load. An optimal value of SM represents a minimum value of LCOE. Solar multiple [47]:

$$
S M=\left.\frac{Q_{\text {coll,SF }}}{Q_{\text {coll,PB }}}\right|_{\text {design-point }}
$$

where $Q_{\text {coll,SF }}$ is the received solar thermal power of the solar field $(\mathrm{kW}) ; Q_{\text {coll,PB }}$ is the required thermal power of the power block $(\mathrm{kW})$.

There are several characteristics, including thermal efficiency, specific steam consumption, and specific heat consumption, that determine the operating performance of the power block in the CSP plant.

The thermal efficiency of the power block can be defined as the following equation.

$$
\eta_{\mathrm{PB}}=\frac{W}{Q} \cdot 100 ; \quad(\%)
$$

where $W$ is the power output of the CSP plant $(\mathrm{kW}) ; Q$ is the quantity of the heat supplied with steam $(\mathrm{kW})$.

The specific steam consumption can be defined as the following equation:

$$
m=\frac{m_{0}}{W} ;(\mathrm{kg} / \mathrm{kW} \cdot \mathrm{h})
$$

where $m_{0}$ is the mass flow rate of the main steam $(\mathrm{kg} / \mathrm{s})$.

The specific heat consumption can be determined by the following equation:

$$
q=\frac{Q}{W} ; \quad(\mathrm{kJ} / \mathrm{kW} \cdot \mathrm{h})
$$

where $Q$ is the quantity of the heat supplied with steam $(\mathrm{kW})$.

Overall solar-to-electric efficiency of the $50 \mathrm{MW}$ CSP plant can be calculated as the following equation [48]:

$$
\eta=\eta_{\mathrm{SF}} \cdot \eta_{\mathrm{PB}} \cdot \eta_{\mathrm{aux}} \cdot \eta_{\text {avia }} ; \%
$$


where $\eta_{\text {aux }}$ is the auxiliary internal power consumption (\%); $\eta_{\text {avia }}$ is the plant availability (\%).

Figure 1 depicts the simplified logic flow diagram for estimating the operating performance of the CSP plant. Input parameters of the CSP plant model were the geographical location (latitude, longitude, and time zone), solar time (hour of the day, day of the year, DNI), collector characteristics (dimensions, length, and mirror properties), and climate data (ambient temperature, pressure, wind speed, and relative humidity). These parameters allowed estimating the performance of the $50 \mathrm{MW}$ CSP plant.

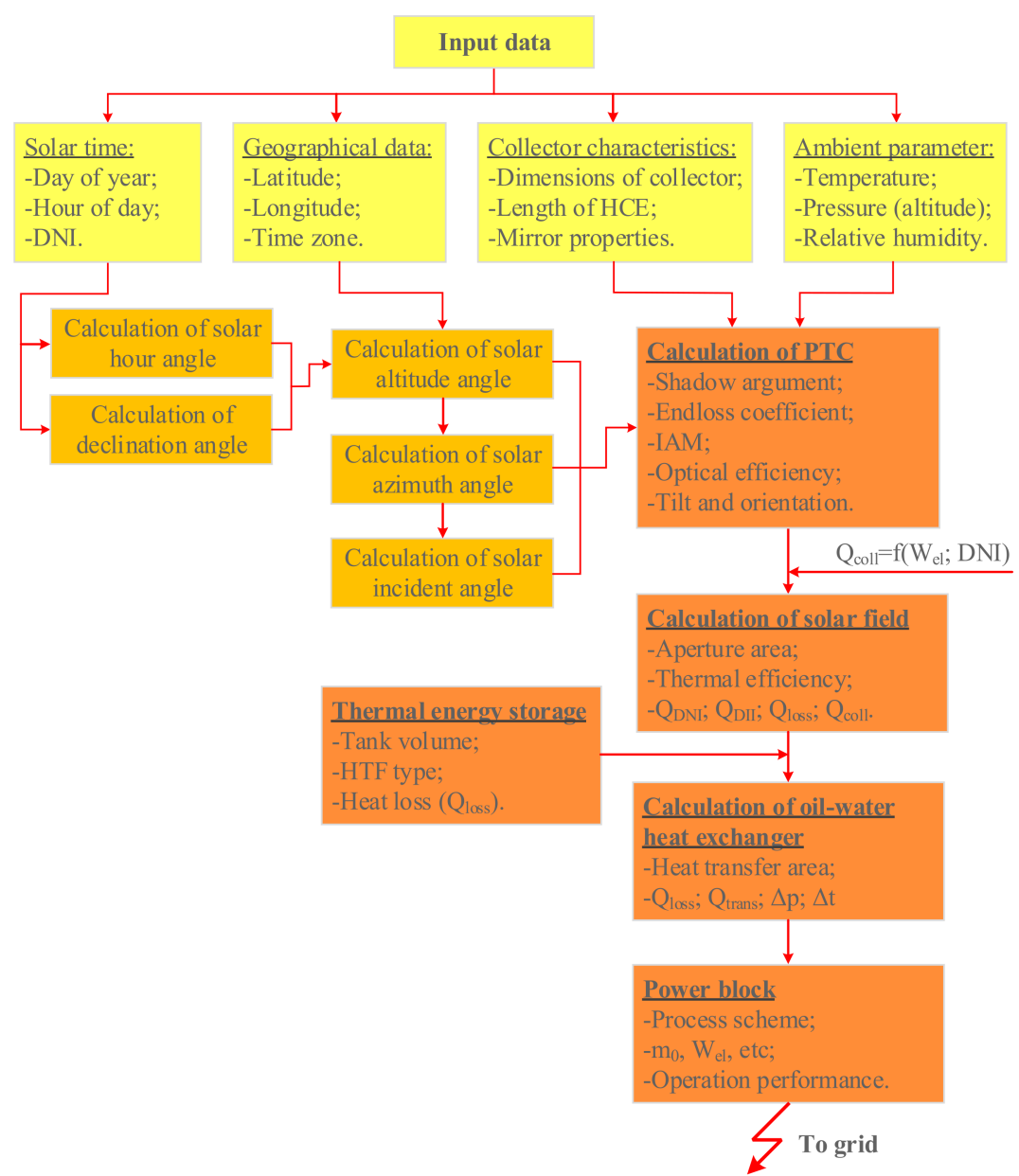

Figure 1. Simplified logic flow diagram for estimating the operating performance of the CSP plant.

The economic analysis of the CSP plant is performed by an estimation of the LCOE [47]. The formulae used for estimating the LCOE of the CSP plant is:

$$
L C O E=\frac{\left(C_{\text {invest }} \cdot C R F\right)+C_{\text {O\&M }}+C_{\text {fuel }}}{E^{\text {an }}}
$$

where $C_{\text {invest }}$ is the total investment of the CSP plant (\$); CRF is the capital recovery factor; $C_{O \& M}$ is the annual operation and maintenance $(\mathrm{O} \& \mathrm{M}) \operatorname{costs}(\$) ; C_{\text {fuel }}$ is the annual fuel costs (in this case, annual fuel costs are neglected, because the CSP plant has been planned without fossil fuel hybridization.) (\$); $E^{\text {an }}$-annual electricity production of the CSP plant (kWh).

The capital recovery factor can be determined by the following formulae.

$$
C R F=\frac{r(r+1)^{D}}{(r+1)^{D}-1}
$$

where $r$ is the discount rate (\%); $D$ is the lifetime of the proposed system (year). 
Cost data for economic analysis of the 50 MW CSP plant is summarized in Table 2. These cost data have been set according to several references $[41,47,49]$.

Table 2. Cost data for economic analysis of 50 MW CSP plant.

\begin{tabular}{ccc}
\hline Parameters & Units & Values \\
\hline Direct cost (DC) & & \\
\hline Solar field cost & $\$ / \mathrm{m}^{2}$ & 170 \\
HTF cost & $\$ / \mathrm{m}^{2}$ & 70 \\
Power block cost & $\$ / \mathrm{kW}$ & 800 \\
Balance of plant cost & $\$ / \mathrm{kW}$ & 110 \\
TES cost & $\$ / \mathrm{kW}$ th & 70 \\
Contingency & $\%$ of DC & 10 \\
Indirect cost (O and M cost) & $\%$ of DC & 15 \\
Engineering, construction, and project & $\%$ of DC & 3.5 \\
management & $\%$ of DC & 1.5 \\
Engineer, procure, construct & $\%$ & 6 \\
Project, land, management & year & 30 \\
Debt interest rate & &
\end{tabular}

\subsection{Model Validation}

Accuracy of our model and verification of our simulation results are performed under the same design-point parameters and operation conditions used by Montes's model. Montes et al. [47] studied the performance analysis of the $50 \mathrm{MW}$ CSP plant located in Plataforma Solar de Almeria site in Spain. Figure 2 shows the simplified process flow diagram of the $50 \mathrm{MW}$ CSP plant located in Plataforma Solar de Almeria. The verification is conducted by using data of the 50 MW CSP plant according to Figure 2.

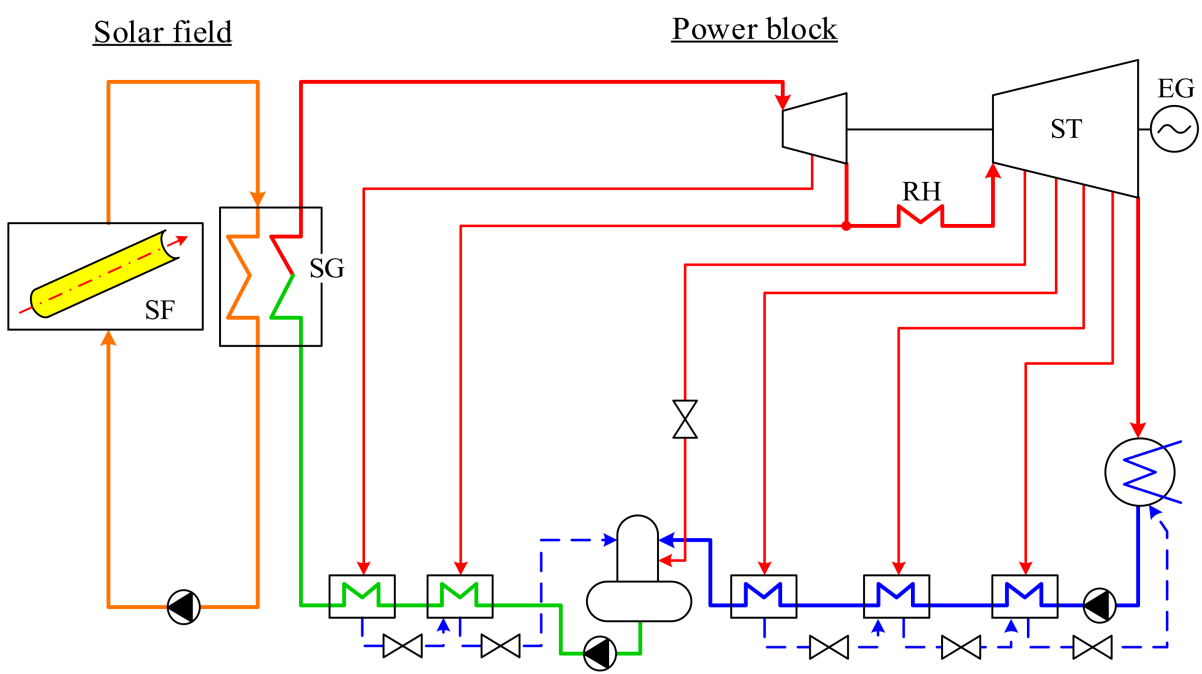

Figure 2. Process flow diagram of the 50 MW CSP plant (Montes's paper): SF-solar field; SG—steam generator; $\mathrm{RH}$-reheater; ST—steam turbine; EG-electric generator.

Comparison of some main parameters and numerical results between Montes's model and our model is clearly described in Table 3. As shown in Table 3, the numerical results of our model agreed well with those reported in Montes's model. Compared results show that the numerical results are the same as Montes's model and satisfy the project modeling requirement, with a relative error range of $0.0 \%$ to about $2.5 \%$. Higher error percentages related to the solar thermal power, the mass flow rate of the main steam, and heat input of reheater are attributed to the uncertainty of some technical specifications of the $50 \mathrm{MW}$ CSP plant in Montes's model during the modeling procedure. 
Table 3. Comparison of the main parameters and numerical results of $50 \mathrm{MW}$ CSP plant.

\begin{tabular}{ccccc}
\hline Parameters & Units & Montes's Model & Our Model & Error, $\%$ \\
\hline DNI & $\mathrm{W} / \mathrm{m}^{2}$ & 850 & 850 & 0.00 \\
Location (longitude and latitude) & $\circ$ & $2.21^{\circ} \mathrm{W}, 37.05^{\circ} \mathrm{N}$ & $2.21^{\circ} \mathrm{W}, 37.05^{\circ} \mathrm{N}$ & 0.00 \\
Altitude & $\mathrm{m}$ & 366 & 366 & 0.00 \\
Ambient temperature & ${ }^{\circ} \mathrm{C}$ & 25 & 25 & 0.00 \\
Collector type & - & $\mathrm{ET}-150$ & $\mathrm{ET}-150$ & - \\
Number of loops & - & 80 & 80 & 0.00 \\
Solar multiple & - & 1.03 & 1.03 & 0.00 \\
Solar thermal power & $\mathrm{MW}$ & 150.3 & 51.71 & 2.80 \\
Power output & $\mathrm{MW}$ & 51.5 & 370 & 0.41 \\
Main steam temperature & ${ }^{\circ} \mathrm{C}$ & 370 & 90 & 0.00 \\
Main steam pressure & $\mathrm{bar}$ & 90 & 370 & 0.00 \\
Reheated steam temperature & ${ }^{\circ} \mathrm{C}$ & 370 & 0.08 & 0.00 \\
Exhausted steam pressure & $\mathrm{bar}$ & 0.08 & 226.56 & 0.00 \\
Mass flow rate of main steam & $\mathrm{t} / \mathrm{h}$ & 228.31 & 37.26 & 0.76 \\
Thermal efficiency of the PB & $\%$ & 38.20 & 121.51 & 2.40 \\
Heat input of a steam generator & $\mathrm{MW}$ & 121.10 & 21.12 & 0.33 \\
Heat input of a reheater & $\mathrm{MW}$ & 21.56 & & 2.00 \\
\hline
\end{tabular}

\section{Results and Discussions}

\subsection{Solar Resource Assessment of the Selected Location}

Mongolia has ample solar resources and favorable climate conditions for effective solar energy utilization. However, Mongolia could not utilize this enormous solar resource to its full potential. Solargis team has created a direct normal irradiation map of Mongolia [50], which is depicted in Figure 3. As shown in Figure 3, the annual received DNI in southern parts of Mongolia is a large number, which is greater than $1700 \mathrm{kWh} / \mathrm{m}^{2}$, and some areas are greater than $2000 \mathrm{kWh} / \mathrm{m}^{2}$. The lowest value of annual DNI was between $1300-1500 \mathrm{kWh} / \mathrm{m}^{2} \mathrm{y}$ in northern parts of the country. Moreover, the highest value of annual DNI was between $1700-2200 \mathrm{kWh} / \mathrm{m}^{2} \mathrm{y}$ in southern parts of the country. According to Mongolia's direct normal irradiation map, the southern desert areas are highly suitable areas for implementing any CSP project.

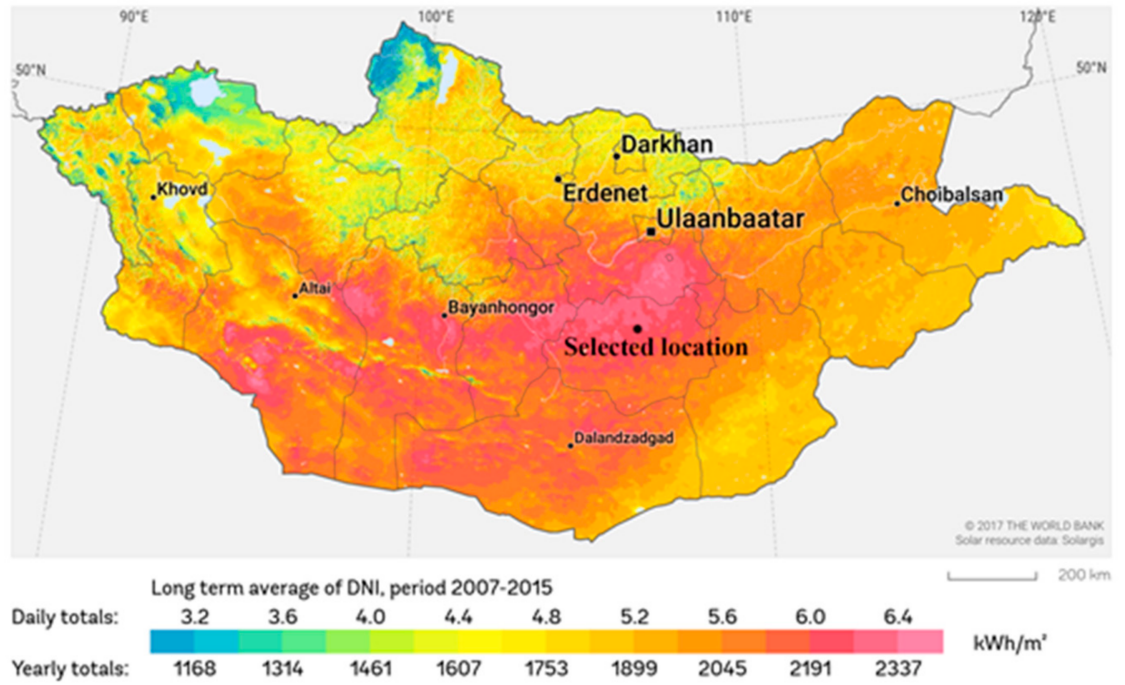

Figure 3. Direct normal irradiation in Mongolia via Solargis data.

The selected location to implement the CSP plant is a key factor to provide maximum solar thermal power and economic benefits from the CSP project. Location of the $50 \mathrm{MW}$ CSP plant is selected in Mandalgobi city of Dundgobi province (longitude: $45.45^{\circ} \mathrm{N}$ and latitude: $106.16^{\circ} \mathrm{E}$ ) due to the higher solar irradiation, more than 3300 sunshine hours in a typical year, a lower density population, and the largest vacant areas, which is appropriate to implement any CSP plant in the future. Moreover, the selected location is near the 
transport logistic system, which is an advantage during installing the CSP plant. According to the Solargis map [50], the daily yearly totals of DNI in the selected location were around $6.2 \mathrm{kWh} / \mathrm{m}^{2}$. day and $2280 \mathrm{kWh} / \mathrm{m}^{2}$.year, respectively.

For the selected location, one-hour solar radiation and climate data from the most recent 15 years (2003-2017) are used [51]. Figure 4 shows the annual distributions of solar and climate data in the selected location. The annual distributions of solar and climate data are run from January 1 to December 31. According to the solar data, the annual DNI of the selected location is around $2160 \mathrm{kWh} / \mathrm{m}^{2}$, which is sufficient to allow the normal operation of the CSP plant. The annual average air temperature and wind speeds in the selected location are around $6-7^{\circ} \mathrm{C}$ and $3.5-4.0 \mathrm{~m} / \mathrm{s}$, respectively. As shown in Figure 5, the selected location was suitable and reliable for solar power generation due to the higher solar radiation resource and favorable climate conditions. However, the ambient temperature in winter is around $-30^{\circ} \mathrm{C}$, which is expected to significantly affect the operation condition of the CSP plant.

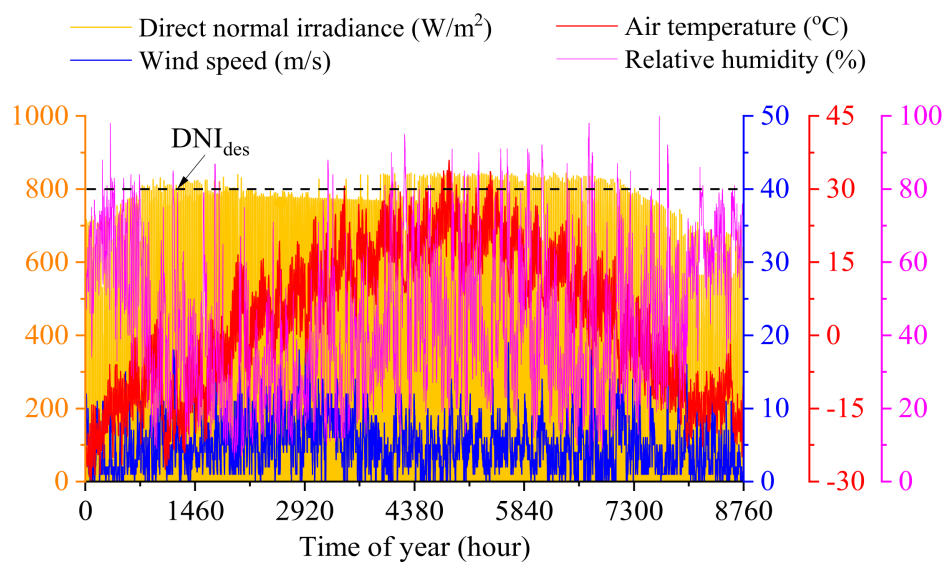

Figure 4. Annual distributions of solar and climate data in the selected location.

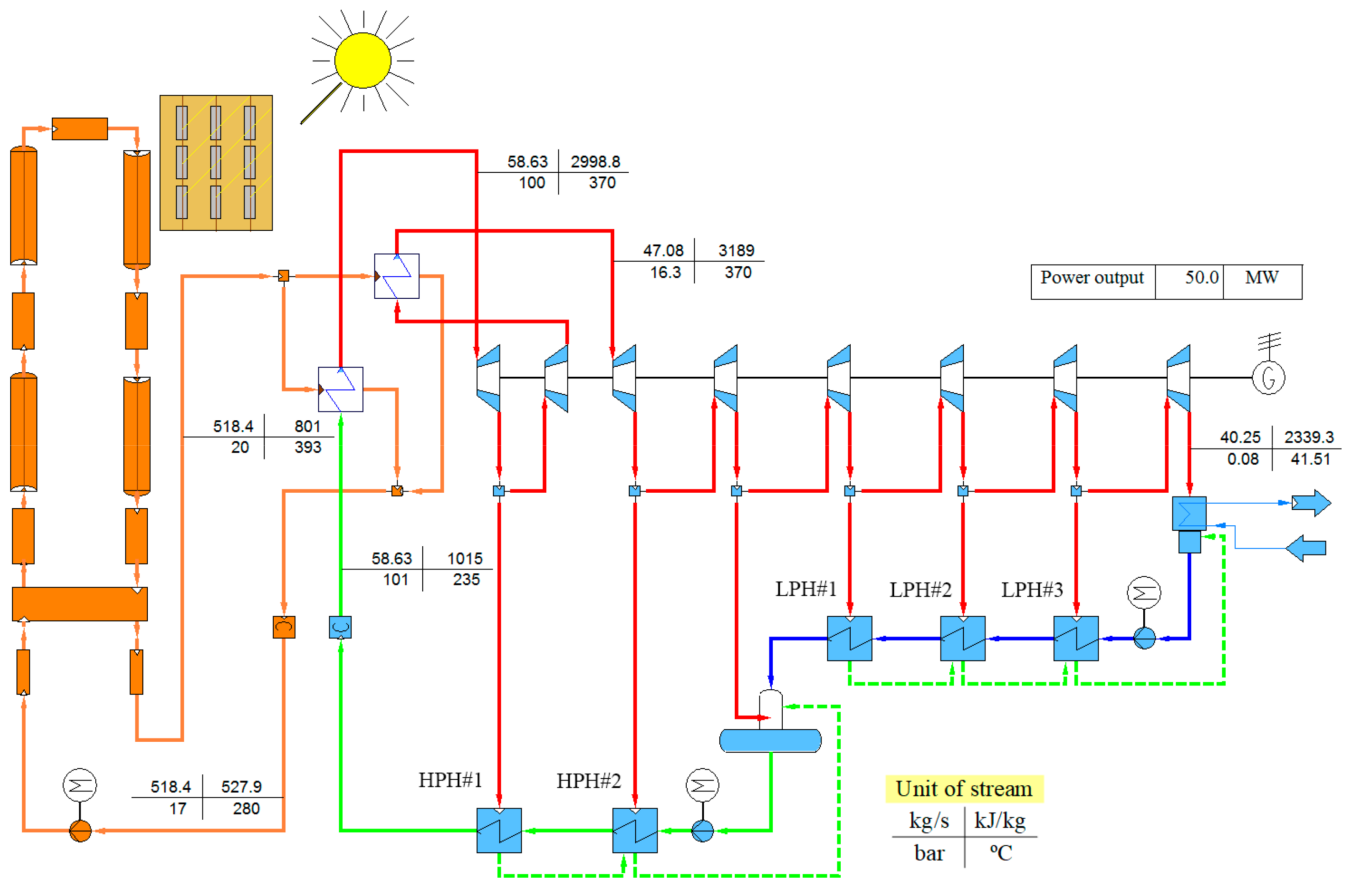

Figure 5. The model of the process flow diagram of the 50 MW CSP plant (IPSEpro model). 


\subsection{Numerical Simulation of the 50 MW CSP Plant in the Design Point Conditions}

A parabolic trough collector is one of the most mature CSP technologies for mediumtemperature applications. The nominal capacity of most commercial CSP plants using PTC technology is around $50 \mathrm{MW}[5,13]$. In this study, the process model of the $50 \mathrm{MW}$ CSP plant was performed on the IPSEpro software based on mass and energy conservation using the technical specification of the Andasol CSP plant. Numerical simulation of the $50 \mathrm{MW}$ CSP plant with nominal load is carried out in the design-point conditions. In Figure 5, the model of the process flow diagram of the 50 MW CSP plant is illustrated. In the process flow diagram described in Figure 5, the power block operates the reheating steam cycle. The feedwater preheating system is composed of two high-pressure preheaters (HPH\#1

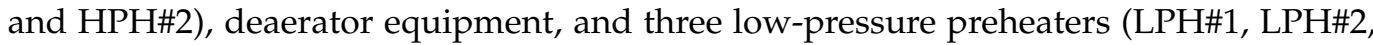
and $\mathrm{LPH} \# 3$ ) connected according to pressure descending order. Deaerator equipment is connected to the third extraction and operates as a separate feedwater preheater.

A temperature-entropy (T-s) diagram of the 50 MW CSP plant cycle with all corresponding intermediate state points in the design point condition is depicted in Figure 6. The general heat transfers and steam expansion process of the $50 \mathrm{MW}$ steam turbine in the CSP plant can be seen in Figure 6. It is pertinent to mention that the steam reheating is after the first steam extraction.

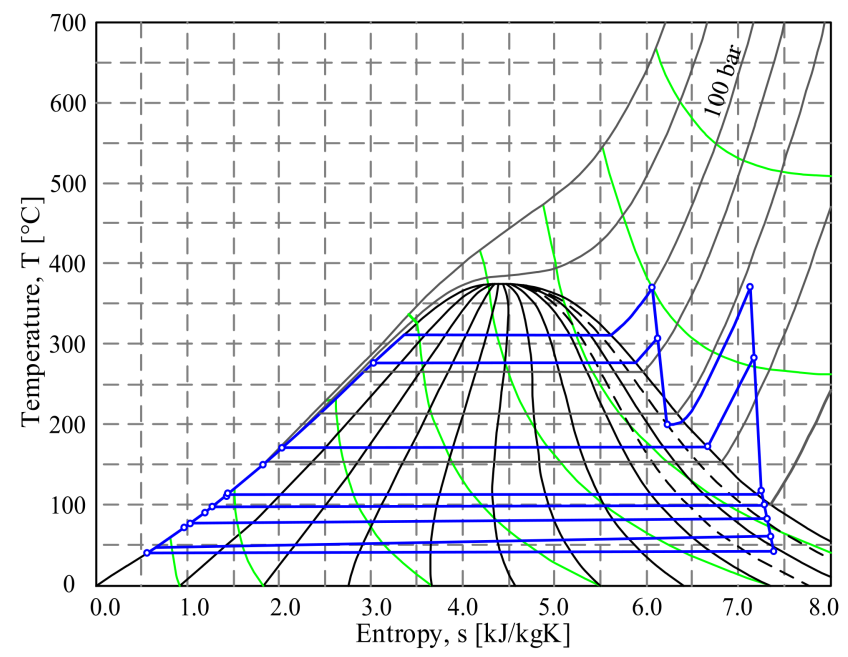

Figure 6. T-s diagram of the steam turbine in the 50 MW CSP plant.

A general layout of the steam generation and steam reheating system of the $50 \mathrm{MW}$ CSP plant based on the design of the Aalborg CSP is shown in Figure 7 [52]. The steam generation system consists of an economizer, feedwater evaporator, and steam superheater. The steam reheating system consists of a low and high-temperature reheater. The temperature balance of working fluids (feedwater, superheated steam, reheated steam, and heat transfer fluid) in the steam generation and the steam reheating system is also shown in Figure 7. In design point condition, the HTF is heated to a maximum of $393{ }^{\circ} \mathrm{C}$ in the solar field and cooled to a temperature of $280{ }^{\circ} \mathrm{C}$ in the steam generator. The mass flow rate of the main steam is around $58.63 \mathrm{~kg} / \mathrm{s}$ per $50 \mathrm{MW}$ electric power output. The main steam is generated at around $100 \mathrm{bar}$ at $370{ }^{\circ} \mathrm{C}$. The mass flow rate of reheated steam is around $47 \mathrm{~kg} / \mathrm{s}$. Outlet steam with a temperature of $200^{\circ} \mathrm{C}$ from the high-pressure cylinder of the turbine is heated in a steam reheater at $370{ }^{\circ} \mathrm{C}(16.3$ bar $)$ again before it enters the low-pressure cylinder of the turbine. 


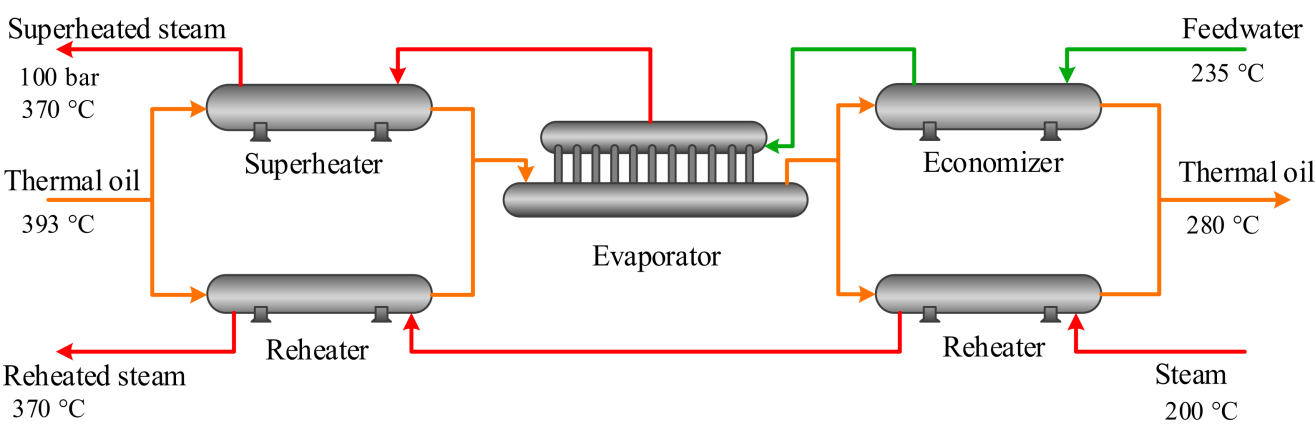

Figure 7. A general layout of the steam generation and steam reheating system of the $50 \mathrm{MW}$ CSP plant.

To calculate the proper solar thermal power received from the solar field, as well as an appropriate aperture area of solar field related to the thermal power required in the power block with nominal load, it needs to set a design point in which the operating performance of solar field is nominal. The design point is set on the 22 June at solar noon. The design point value of DNI is taken as $800 \mathrm{~W} / \mathrm{m}^{2}$, considering the annual distribution of DNI. The parabolic trough collectors in the solar field were arranged along with North-South orientation due to the maximum solar thermal power received from the solar field on a yearly basis. The design parameters and operating performance of the 50 MW CSP plant are calculated at the design point value of DNI and summarized in Table 4.

Table 4. Main parameters and operating performance of $50 \mathrm{MW}$ CSP plant in nominal load.

\begin{tabular}{|c|c|c|}
\hline Parameters & Units & Values \\
\hline \multicolumn{3}{|l|}{ Power block characteristics } \\
\hline Power output (gross) & $\mathrm{kW}$ & 50,000 \\
\hline Pressure of main steam & bar & 100 \\
\hline Temperature of main steam & ${ }^{\circ} \mathrm{C}$ & 370 \\
\hline Pressure of exhausted steam & bar & 0.08 \\
\hline Temperature of reheated steam & ${ }^{\circ} \mathrm{C}$ & 370 \\
\hline Pressure of reheated steam & bar & 16.5 \\
\hline Mass flow rate of main steam & $\mathrm{t} / \mathrm{h}$ & 211.1 \\
\hline Mass flow rate of reheated steam & $t / h$ & 169.5 \\
\hline Mass flow rate of exhausted steam & $t / h$ & 169.5 \\
\hline Temperature of feedwater & ${ }^{\circ} \mathrm{C}$ & 235 \\
\hline Transferred heat into cooling fluid & $\mathrm{kW}$ & 140,160 \\
\hline Thermal efficiency of PB & $\%$ & 35.72 \\
\hline Specific steam consumption of PB & $\mathrm{kg} / \mathrm{kWh}$ & 4.22 \\
\hline Specific heat consumption of $\mathrm{PB}$ & $\mathrm{kJ} / \mathrm{kWh}$ & 10,080 \\
\hline \multicolumn{3}{|l|}{ Solar field characteristics } \\
\hline Type of PTC & - & Eurotrough-150 \\
\hline Design point value of DNI & $\mathrm{kW} / \mathrm{m}^{2}$ & 0.80 \\
\hline Number of loops & - & 80 \\
\hline Aperture area of the SF & $\mathrm{m}^{2}$ & 261,600 \\
\hline DNI on aperture area & $\mathrm{kW}$ & 209,280 \\
\hline Heat gain of collector from DII & $\mathrm{kW}$ & 151,744 \\
\hline Optical and thermal heat loss of SF & $\mathrm{kW}$ & 68,230 \\
\hline Transferred heat into HTF & $\mathrm{kW}$ & 141,050 \\
\hline Temperature of HTF at the outlet to the SF & ${ }^{\circ} \mathrm{C}$ & 395 \\
\hline Temperature of HTF at the inlet to the SF & ${ }^{\circ} \mathrm{C}$ & 280 \\
\hline Mass flow rate of HTF & $\mathrm{t} / \mathrm{h}$ & 1866 \\
\hline Thermal efficiency of the SF & $\%$ & 67.4 \\
\hline Overall solar-to-electric efficiency of CSP plant & $\%$ & 22.03 \\
\hline
\end{tabular}

\subsection{Numerical Simulation of the 50 MW CSP Plant in the Part-Load Condition}

Due to the fluctuation of solar irradiation, solar thermal power produced from the solar field is always changed. On the other hand, the power block operates in partload conditions when insufficient solar thermal power is available. For that reason, it is significantly important to analyze the operating performance of the CSP plant in the part-load conditions. Numerical simulation of the 50 MW CSP plant is carried out in the part-load conditions by considering the variation of power output from $50 \mathrm{MW}$ to $30 \mathrm{MW}$. 
Figure 8 depicts the effect of power output on the mass flow rates of the main steam, reheated steam, and exhausted steam. When the CSP plant is the nominal load of $50 \mathrm{MW}$, the mass flow rates of the main, reheated, and exhausted steam are at design point values. However, reducing the rated power output could result in the reduction of the mass flow rates of the main steam, reheated steam, and exhausted steam.

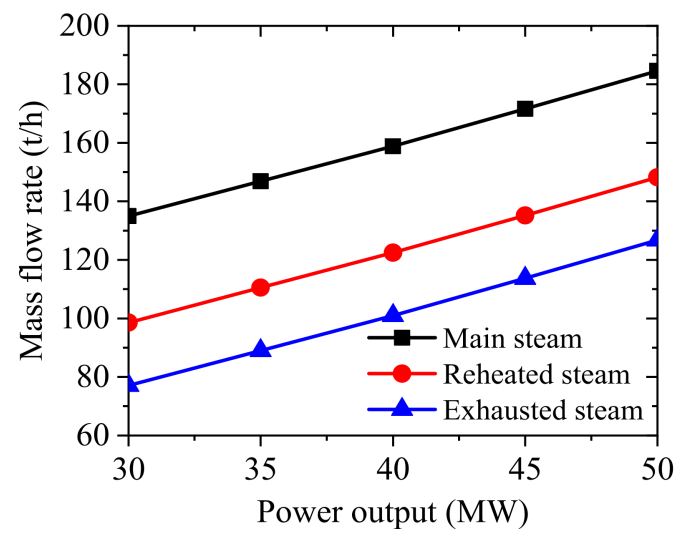

Figure 8. Effect of power output on the mass flow rates of main, reheated, and exhausted steam.

The operating performance of the power block in the CSP plant is characterized by thermal efficiency, specific steam consumption, and specific heat consumption. Figure 9 depicts the effect of the power output on the operating performance of the CSP plant. From Figure 9, the operating performance of the power block can decrease by reducing power output due to part-load conditions. The results revealed that the efficient and economical operation condition of the CSP plant is near the nominal load. For instance, operating performance is at maximum when the CSP plant operates at a nominal load. It is relevant to mention that the operating performance of the CSP plant is always changed due to the fluctuation of solar irradiation.

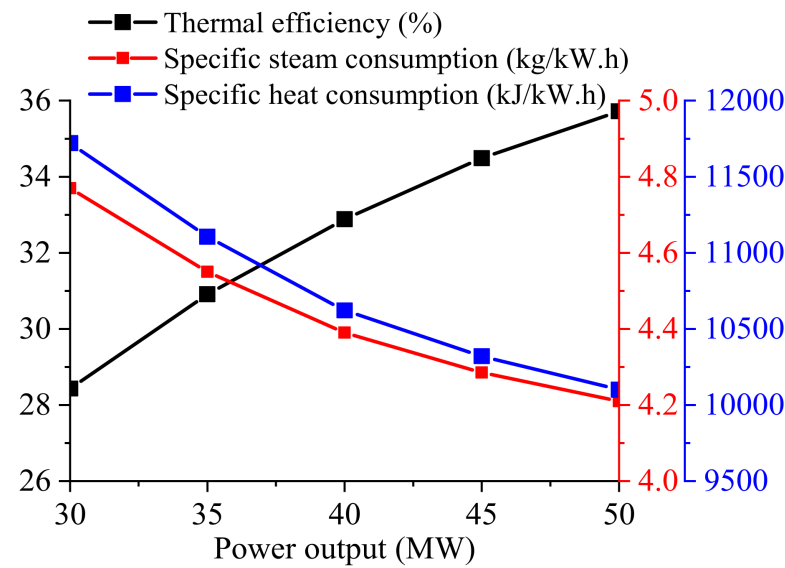

Figure 9. Effect of power output on the operating performance of the power block.

\subsection{Optimization for Aperture Area of the Solar Field}

DNI value of each day in a typical year is different, and the calculation of the aperture area of the solar field is significantly important for the investment costs of the CSP plant. When the real climate condition is cloudy, the DNI value is lower than the clear climate condition. Moreover, solar energy does not continuously shine the solar field and is interrupted during cloudy and rainy days. When the aperture area of the solar field is large, solar energy will be partially useless under a higher DNI value. In contrast, when the aperture area of the solar field is small, the power block will be operated in the part-load 
conditions. Hence, the optimization for the aperture area of the solar field is economically important.

In this study, a solar multiple is used to calculate the optimal aperture area of the solar field. To estimate the optimal value of SM, ten aperture areas of the solar field from 60 loops to 200 loops have been studied. The SM value varies from 0.75 to 2.5 and solar multiple calculations for each aperture area of the solar field are given in Table 5. The thermal power required in the power block is the same for each SM. On the other hand, the solar thermal power received from the solar field is increased with the growth of the aperture area of the solar field. However, the optical and thermal losses of the solar field also increase with the growth of the aperture area.

Table 5. Calculation of solar multiple.

\begin{tabular}{ccccc}
\hline $\begin{array}{c}\text { Solar } \\
\text { Multiple }\end{array}$ & $\begin{array}{c}\text { Number of } \\
\text { Loops }\end{array}$ & $\begin{array}{c}\text { Aperture Area } \\
\text { of SF, } \mathbf{~ m}^{\mathbf{2}}\end{array}$ & $\begin{array}{c}\text { Solar Thermal Power } \\
\text { Received from SF, MW }\end{array}$ & $\begin{array}{c}\text { Thermal Power } \\
\text { Required in PB, MW }\end{array}$ \\
\hline 0.750 & 60 & 196,200 & 105.78 & 140.16 \\
0.875 & 70 & 228,900 & 123.42 & 140.16 \\
1.000 & 80 & 261,600 & 141.05 & 140.16 \\
1.125 & 90 & 294,300 & 158.68 & 140.16 \\
1.250 & 100 & 327,000 & 176.31 & 140.16 \\
1.500 & 120 & 392,400 & 211.57 & 140.16 \\
1.750 & 140 & 457,800 & 246.84 & 140.16 \\
2.000 & 160 & 523,200 & 282.10 & 140.16 \\
2.250 & 180 & 588,600 & 317.36 & 140.16 \\
2.500 & 200 & 654,000 & 352.62 & 140.16 \\
\hline
\end{tabular}

The effect of solar multiple on the LCOE of the 50 MW CSP plant is considered in the design point condition, which is shown in Figure 10. The result shows that the SM corresponding to the minimum value of LCOE is around 2.0. As can be seen in Figure 10, the LCOE decreases first until the minimum value, before it quickly increases. The minimum LCOE was $0.2143 \$ / \mathrm{kWh}$, considering the optimal aperture area of the solar field. On the other hand, the optimal aperture area of the SF was estimated as $523,200 \mathrm{~m}^{2}$ corresponding to the minimum LCOE. From the literature review, the LCOE of the CSP plant is depending on the geographical location, DNI, climate conditions, system capacity, and operation hours of the TES system, and other studies reported the LCOE in 50 MW CSP plant as $0.1506 \$ / \mathrm{kWh}$ by Sultan et al. [19], $0.16 \$ / \mathrm{kWh}$ by Shafiee et al. [22], and $0.17 \$ / \mathrm{kWh}$ by Llamas et al. [53].

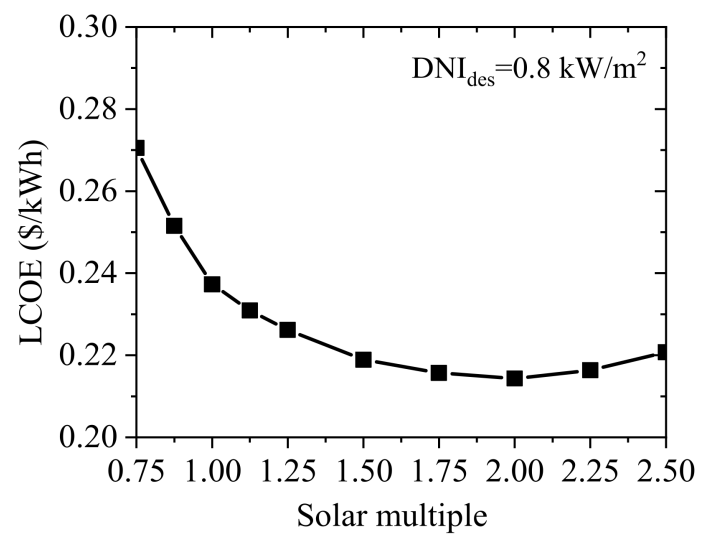

Figure 10. LCOE for every solar multiple.

3.5. Effect of Variation of DNI on the Operating Performance of the Solar Field in the Design Point Conditions

In this section, the operating performance of the solar field has been obtained under different DNI values. In practice, the solar field of the CSP plant operates in the part-load 
conditions, which depends on the variation of DNI that may continuously vary. Thus, it is significantly important to analyze the operating performance of the solar field in the part-load conditions considering the variation of DNI. Table 6 provides the operating performance of the solar field in the part-load conditions under design-point. The effect of variation of DNI on the operating performance of the solar field was analyzed for ranging from $1.00 \mathrm{~kW} / \mathrm{m}^{2}$ to $0.2 \mathrm{~kW} / \mathrm{m}^{2}$ under design point (22nd of June). The operating parameters of the solar field include thermal efficiency of the solar field, DNI on an aperture area of the solar field, heat gain of collector from DII, heat loss of collector, heat absorbed in the solar field by the HTF, mass flow rate of HTF, and outlet and inlet temperature of HTF. These parameters are the determining characteristics for calculating the operating performance of the solar field. To maintain the outlet temperature of HTF at the constant design-point temperature of $393^{\circ} \mathrm{C}$, the mass flow rate of HTF can be adapted by controlling the HTF pump according to the variation of DNI.

Table 6. The operating performance of the solar field in the part-load condition.

\begin{tabular}{cccccccccccc}
\hline Parameters & Units & \multicolumn{7}{c}{ Values } \\
\hline DNI & $\mathrm{kW} / \mathrm{m}^{2}$ & 1.00 & 0.90 & 0.80 & 0.70 & 0.60 & 0.50 & 0.40 & 0.30 & 0.20 \\
\hline DII & $\mathrm{kW} / \mathrm{m}^{2}$ & 0.725 & 0.653 & 0.580 & 0.508 & 0.435 & 0.363 & 0.290 & 0.218 & 0.145 \\
\hline Aperture area of SF & $\mathrm{m}^{2}$ & 523,200 & 523,200 & 523,200 & 523,200 & 523,200 & 523,200 & 523,200 & 523,200 & 523,200 \\
\hline Thermal efficiency of SF & $\%$ & 68.4 & 68.0 & 67.4 & 66.7 & 65.7 & 64.3 & 62.3 & 58.9 & 52.0 \\
\hline DNI on aperture area of SF & $\mathrm{kW}$ & 523,200 & 470,880 & 418,560 & 366,240 & 313,920 & 261,600 & 209,280 & 156,960 & 104,640 \\
\hline $\begin{array}{c}\text { Heat gain of collector } \\
\text { from DII }\end{array}$ & $\mathrm{kW}$ & 379,358 & 341,422 & 303,486 & 265,550 & 227,615 & 189,679 & 151,743 & 113,807 & 75,872 \\
\hline Heat loss of collector & $\mathrm{kW}$ & 165,218 & 150,835 & 136,452 & 122,070 & 107,690 & 93,311 & 78,937 & 64,570 & 50,230 \\
\hline $\begin{array}{c}\text { Heat absorbed in the SF by } \\
\text { the HTF }\end{array}$ & $\mathrm{kW}$ & 357,982 & 320,045 & 282,108 & 244,170 & 206,230 & 168,289 & 130,343 & 92,390 & 54,410 \\
\hline Mass flow rate of HTF & $\mathrm{t} / \mathrm{h}$ & 1315.1 & 1175 & 1036 & 896.3 & 756.8 & 617.5 & 478.1 & 338.8 & 199.4 \\
\hline Outlet temperature of HTF & ${ }^{\circ} \mathrm{C}$ & 393 & 393 & 393 & 393 & 393 & 393 & 393 & 393 & 393 \\
\hline Inlet temperature of HTF & ${ }^{\circ} \mathrm{C}$ & 280 & 280 & 280 & 280 & 280 & 280 & 280 & 280 & 280 \\
\hline
\end{tabular}

The effect of variation of DNI on the operation performance of the solar field is shown in Figure 11. The DNI on an aperture area of the solar field, heat gain of collector from DII, heat loss of collector, and heat absorbed in the solar field by the HTF are considered under variations of DNI. As shown in Figure 11, the DNI is a key factor that significantly influences the operation performance of the solar field. Results revealed that the solar field was of good operation performance under higher DNI conditions. However, optical and thermal losses also increase when the DNI value grows.

The effect of the outlet temperature of the HTF on the operating parameters of the solar field was analyzed for temperatures ranging from $350{ }^{\circ} \mathrm{C}$ to $410{ }^{\circ} \mathrm{C}$ under design point DNI condition $\left(\mathrm{DNI}=0.8 \mathrm{~kW} / \mathrm{m}^{2}\right)$, as shown in Figure 12. The effect of the outlet temperature of the HTF on the mass flow rate of HTF and power consumption of the HTF pump is shown in Figure 12a. From Figure 12a, the mass flow rate of HTF and power consumption of HTF pump are decreased with the increase of outlet temperature of the HTF under design-point DNI condition. The effect of the outlet temperature of the HTF on the thermal efficiency and heat loss of the solar field is shown in Figure 12b. From Figure 12b, the thermal efficiency of the solar field has decreased due to the increase of heat loss of the solar field when the outlet temperature of HTF has increased. Results show that increasing the outlet temperature of HTF has the advantage of reducing the mass flow rate of HTF, thereby reducing the power consumption of the HTF pump. On the other hand, increasing the outlet temperature of HTF will increase heat loss of the solar field, and thus the thermal efficiency of the solar field reduces. 


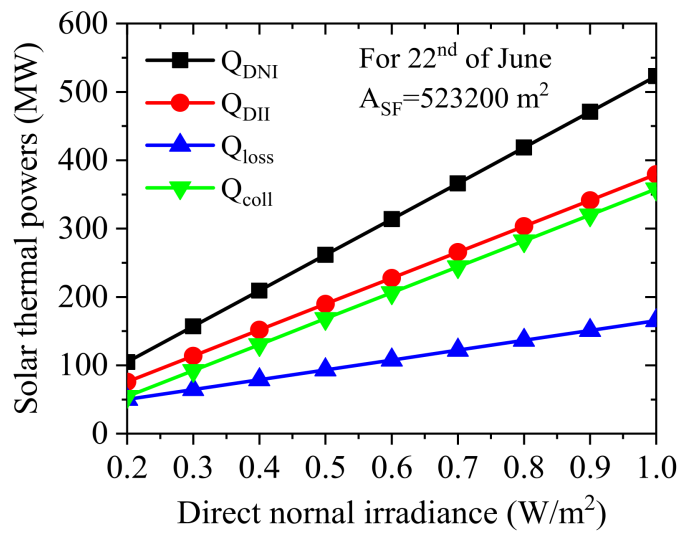

Figure 11. Effect of variation of DNI on the operation performance of the solar field: $\left(Q_{\mathrm{DNI}}\right.$ is the DNI on an aperture area of the solar field; $Q_{\mathrm{DII}}$ is the heat gain of collector from DII; $Q_{\text {loss }}$ is the heat loss of collector; $Q_{\text {coll }}$ is the heat absorbed in the solar field by the HTF).

(a)

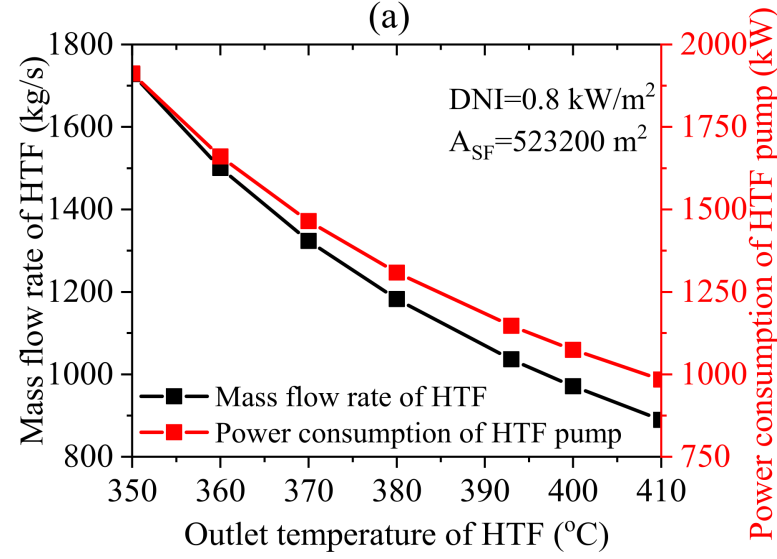

(b)

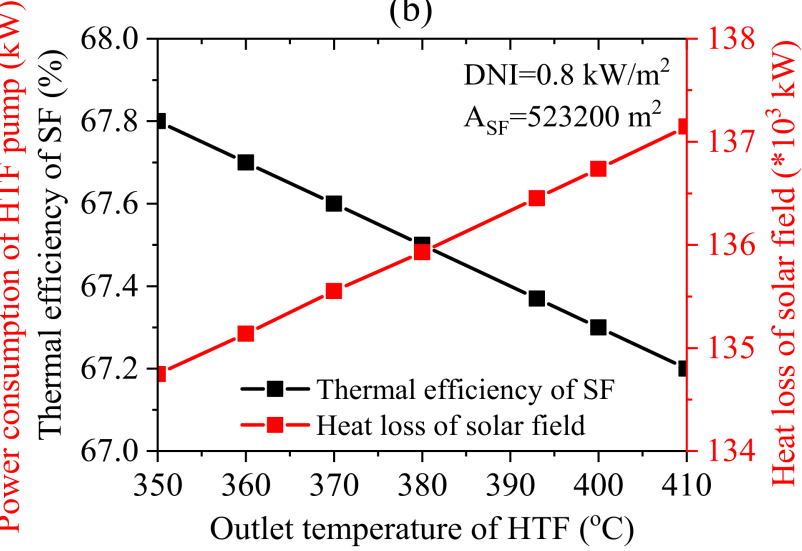

Figure 12. Effect of outlet temperature of the HTF on the operating parameters of the solar field: (a) mass flow rate of HTF and power consumption of HTF pump; (b) thermal efficiency and heat loss of the solar field.

\subsection{Operating Performance of the 50 MW CSP Plant under Four Reference Days}

To evaluate the operating condition of the 50 MW CSP plant, it is investigated under four different reference days in Mongolian climate conditions. In this study, the 22 March, 22 June, 22 September, and 22 December are selected as the four reference days in a typical meteorological year. The selected four reference days represent the four seasons of the year. Figure 13 clearly describes the daily variations of DNI and solar incidence angle under four different reference days. As described in Figure 13a, the DNI value is the highest on the 22 June and the lowest on the 22 December. It was found that the DNI increases sharply at first, reaches the maximum value between 10:00 and 14:00, and then decreases by the changing of the Sun race. As described in Figure 13b, the solar incidence angles are maximum for the 22 January and minimum for the 22 June, as estimated. The variations of DNI and solar incidence angle on 22 March are almost similar to those on 22 September. For the 22 June, the solar incidence angle is visibly smaller compared to the other three days, which is lower than $20^{\circ}$. In contrast, the solar incidence angle for the 22 December is the largest in four typical reference days, which is around $66^{\circ}$. The results indicate that the solar incidence angle has the largest effect on the absorbed solar thermal power from the solar field. 
(a)

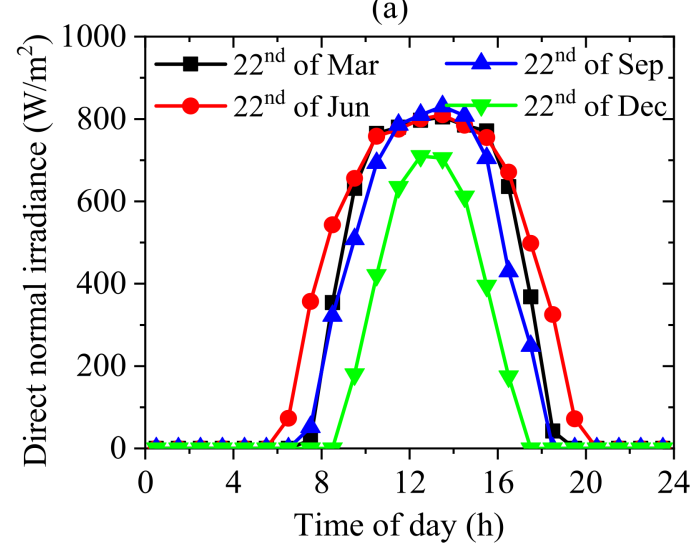

(b)

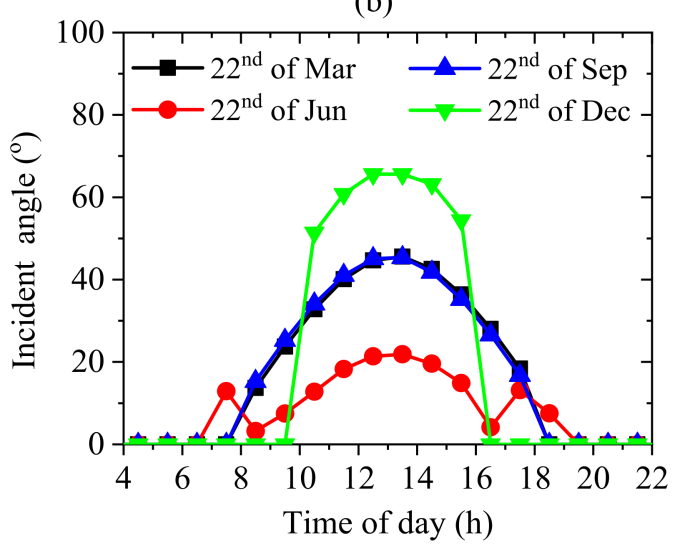

Figure 13. Daily variations of (a) DNI and (b) solar incidence angle under four different reference days.

The following characteristics, such as the mass flow rate of the HTF, absorbed solar thermal power from the solar field, and thermal efficiency of the solar field, are the key characteristics for evaluating the operating performance of the solar field. Figure 14 depicts the daily variations of the operating performance of the solar field under four different reference days. The operating performance of the solar field is obtained at higher values in the spring, summer, and autumn seasons. On the other hand, the lowest value of operating performance occurred in the winter season due to the decrease of DNI value and the increase of solar incidence angle. The operating performance of the solar field mainly depends on DNI and solar incidence angle. Due to the solar incidence angle, the operating performance of the solar field decreases at noon under four reference days when the DNI value is higher. In all reference days, the operational performances of the solar field are a higher value between 10:00 and 16:00. However, there are two peak values of the operating performance of the solar field between 9:00 and 11:00 and between 15:00 and 18:00 under four different reference days, which are caused by the DNI value and solar incidence angle. In other words, DNI is the highest value during 12:00-13:00, and the solar incidence angle is significantly high during this period, which reduces the thermal efficiency of the solar field due to the larger optical loss. Similar observations were found in the numerical studies of Shagdar et al. [54] and Chen et al. [55]. The solar field exhibited a very good capability to collect solar thermal power during summer days, whereas during winter days, the operating performance of the solar field was significantly reduced due to a decrease in DNI and ambient temperature and an increase in solar incidence angle.
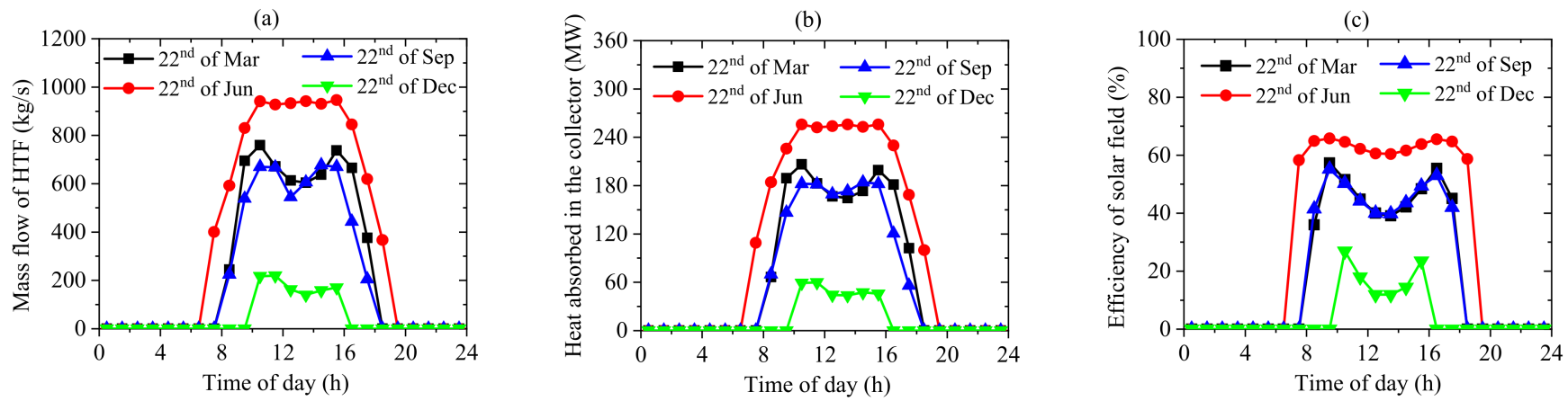

Figure 14. Daily variations of the operating performance of the SF under four different reference days: (a) mass flow rate of HTF; (b) heat amount absorbed in the solar field; (c) thermal efficiency of the solar field.

To evaluate the power generation of the CSP plant throughout the year, daily variation of the power output of the $50 \mathrm{MW}$ CSP plant is examined under four different reference days, which is depicted in Figure 15. The simulation results show that the power generation 
of the CSP plant is significantly changed during the year due to the season. For instance, the 50 MW CSP plant can generate 580.12 MWh, 867.64 MWh, 511.76 MWh, and 105.31 MWh of electricity during the four different reference days, respectively.

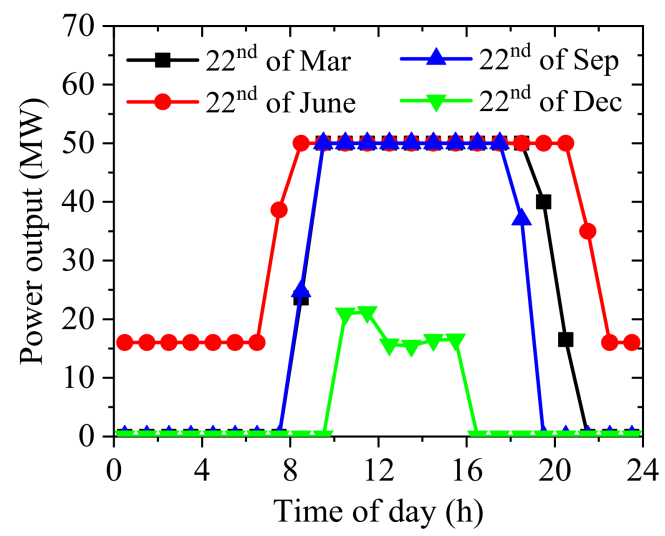

Figure 15. Daily variation of power generation of CSP plant under four different reference days.

The effect of the TES system on power generation is evident as shown in Figure 15. The TES system is filled up on summer days, which is extended to the operation hours of the CSP plant during evening and night times. Consequently, the CSP plant can generate power output per hour around $50 \mathrm{MW}$ from $8 \mathrm{~h}$ to $21 \mathrm{~h}$ on the $22 \mathrm{July}$. On the 22 December, the CSP plant can generate a little amount of power output from $10 \mathrm{~h}$ to $16 \mathrm{~h}$. The solar field collected a different amount of solar thermal power on four different reference days. This collected solar thermal power is supplied to the power block as well as the TES system. For instance, solar thermal powers absorbed in the solar field by the HTF are 162.9 MW, 254.1 MW, 146.6 MW, and 297.5 MW for the 22 March, 22 June, 22 September, and 22 December, respectively. The TES system is charged during the day when additional solar thermal power is available and supplies this stored solar thermal power to the power block when solar energy is unavailable. For the 22 June, the 50 CSP plant can produce 295 MWh of additional electricity using the TES system. Moreover, the 50 CSP plant can produce 75 MWh of electricity using the TES system on the 22 September. Besides, the 50 CSP plant can produce $107 \mathrm{MWh}$ of electricity using the TES system on the $22 \mathrm{March}$. On the other hand, the TES system cannot be used in the 50 CSP plant during the winter season. For example, the 50 CSP plant can only produce $105 \mathrm{MWh}$ of electricity on the 22 December, which is caused by the decrease of DNI value, decrease of ambient temperature, and increase of solar incidence angle. Results revealed that the highest power generation of the CSP plant is in June, and the lowest is in December. Moreover, power generation for March and September are almost similar. The power generation of the CSP plant is mainly affected by the DNI value and solar incidence angle.

\section{Conclusions}

In this study, the performance analysis of the 50 MW CSP plant was investigated for four different reference days (i.e., 22 March, 22 June, 22 September, and 22 December). Numerical simulation of the $50 \mathrm{MW}$ CSP plant was performed both at nominal and partload conditions, considering the effects of several variations, including the power load and solar radiation. The results show that the operating performance of the CSP plant was strongly affected by the solar radiation and solar incidence angle. Moreover, the operating performance of the CSP plant in the part-load conditions was significantly reduced compared to the nominal load. For instance, the efficient and economical mode of the CSP plant is near the nominal load, which is around $50 \mathrm{MW}$.

The results also show that, except for the winter season, the rest of the reference days represent the best period with higher operating performance for the $50 \mathrm{MW} \mathrm{CSP}$ plant. For example, the highest value of the operating performance of the $50 \mathrm{MW}$ CSP plant is for 
the 22 June and the lowest value for the 22 January. Moreover, the operating performance on the 22 March is almost similar to the 22 September. Although the results revealed that the 50 MW CSP plant could operate well throughout the year, the winter season has been expected to significantly affect the operating performance of the CSP plant due to the solar incidence angle, duration of sunshine, and ambient temperature. Except for the winter season, the power generation of the CSP plant can be significantly increased due to the TES system. For instance, the $50 \mathrm{MW}$ CSP plant can produce $295 \mathrm{MW} \cdot \mathrm{h}, 75 \mathrm{MW} \cdot \mathrm{h}$, and $107 \mathrm{MW} \cdot \mathrm{h}$ of additional power generation with the aid of the TES system on the 22 June, 22 September, and 22 March, respectively. In addition, the minimum LCOE was 0.214 $\$ / \mathrm{kWh}$, considering the optimal aperture area of the solar field $\left(523,200 \mathrm{~m}^{2}\right)$.

Author Contributions: All authors contributed to the attainment of this work as follows: conceptualization, methodology, software, writing—original draft preparation, writing—review and editing, E.S.; supervision, writing-review and editing, funding acquisition, B.G.L.; methodology, supervision, conceptualization, B.S.; supervision, funding acquisition, Y.S.; writing-review and editing, data curation, A.M.; software, data curation, validation, E.G.; methodology, data curation, D.H. All authors have read and agreed to the published version of the manuscript.

Funding: This work was supported by the National Key R and D Program of China (No. 2018YFA0702300), the National Natural Science Foundation of China (No. 51950410590), and funding for research projects of the Chinese Society for Degree and Graduate Education (No. 2020MSA352).

Institutional Review Board Statement: Not applicable.

Informed Consent Statement: Not applicable.

Data Availability Statement: Not applicable.

Acknowledgments: The authors are pleased to thank reviewers and people who suggest improvements in the manuscript. Moreover, the authors thank SimTech $\mathrm{GmbH}$ and Bensheim-engineers $\mathrm{GmbH}$ for professional advising.

Conflicts of Interest: The authors declare no conflict of interest.

\section{Nomenclature}

$\begin{array}{ll}\text { CSP } & \text { Concentrating solar power } \\ \text { DC } & \text { Direct cost } \\ \text { DII } & \text { Direct incident irradiation } \\ \text { DNI } & \text { Direct normal irradiance } \\ \text { EG } & \text { Electric generator } \\ \text { ET-150 } & \text { Eurotrough-150 collector } \\ \text { HT } & \text { Hot tank } \\ \text { HTF } & \text { Heat transfer fluid } \\ \text { HPH } & \text { High-pressure heater } \\ \text { IAM } & \text { Incident angle modifier } \\ \text { IEA } & \text { International Energy Agency } \\ \text { IPSEpro } & \text { Integrated process simulation environment } \\ \text { LCOE } & \text { Levelized cost of electricity } \\ \text { LFC } & \text { Linear Fresnel collectors } \\ \text { LPH } & \text { Low-pressure heater } \\ \text { O\&M } & \text { Operation and maintenance } \\ \text { PB } & \text { Power block } \\ \text { PD } & \text { Parabolic dish } \\ \text { PTC } & \text { Parabolic trough collector } \\ \text { PV } & \text { Photovoltaic } \\ \text { SAM } & \text { System advisor model } \\ \text { SF } & \text { Solar field } \\ \text { SG } & \text { Steam generator } \\ \end{array}$


SM Solar multiple

SPT Solar power tower

ST Steam turbine

RH Reheater

\section{References}

1. IPCC. Climate Change 2014: Mitigation of Climate Change. Assessment Report of the Intergovernmental Panel on Climate Change; Cambridge University Press: Cambridge, UK; New York, NY, USA, 2014.

2. International Energy Agency. Technology Roadmap: Concentrating Solar Power; International Energy Agency: Paris, France, 2010; Volume 5.

3. Răboacă, M.S.; Badea, G.; Enache, A.; Filote, C.; Răsoi, G.; Rata, M.; Lavric, A.; Felseghi, R.-A. Concentrating Solar Power Technologies. Energies 2019, 12, 1048. [CrossRef]

4. Sciuto, G.L.; Capizzi, G.; Caramagna, A.; Famoso, F.; Lanzafame, R.; Wozniak, M. Failure classification in high concentration photovoltaic system (HCPV) by using probabilistic neural networks. Int. J. Appl. Eng. Res. 2017, 12, 16039-16046.

5. Awan, A.B.; Khan, M.; Zubair, M.; Bellos, E. Commercial parabolic trough CSP plants: Research trends and technological advancements. Sol. Energy 2020, 211, 1422-1458. [CrossRef]

6. Sciuto, G.L.; Cammarata, G.; Capizzi, G.; Coco, S.; Petrone, G. Design optimization of solar chimney power plant by finite elements based numerical model and cascade neural networks. In Proceedings of the 2016 International Symposium on Power Electronics, Electrical Drives, Automation and Motion (SPEEDAM), Capri, Italy, 22-24 June 2016; pp. 1016-1022. [CrossRef]

7. Caicedo, P.; Wood, D.; Johansen, C. Radial Turbine Design for Solar Chimney Power Plants. Energies 2021, 14, 674. [CrossRef]

8. Shagdar, E.; Shuai, Y.; Lougou, B.G.; Jagvanjav, T.-O.; Wang, F.; Tan, H. Comparative Performance Assessment of 300 MW Solar-Coal Hybrid Power Generation System Under Different Integration Mechanisms. Energy Technol. 2021, 9, 1-15. [CrossRef]

9. Arnaoutakis, G.E.; Katsaprakakis, D.A. Concentrating Solar Power Advances in Geometric Optics, Materials and System Integration. Energies 2021, 14, 6229. [CrossRef]

10. Shagdar, E.; Lougou, B.G.; Shuai, Y.; Ganbold, E.; Chinonso, O.P.; Tan, H. Process analysis of solar steam reforming of methane for producing low-carbon hydrogen. RSC Adv. 2020, 10, 12582-12597. [CrossRef]

11. Dessie, Y.G.; Lougou, B.G.; Hong, Q.; Heping, T.; Qi, H.; Baohai, G.; Arafat, I.M. Thermal Performance Analysis of a Solar Reactor Designed for Syngas Production. Energies 2020, 13, 3405. [CrossRef]

12. Lougou, B.G.; Shuai, Y.; Chaffa, G.; Ahouannou, C.; Pan, R.; Zhang, H.; Tan, H. Analysis of Two-Step Solar Thermochemical Looping Reforming of $\mathrm{Fe}_{3} \mathrm{O}_{4}$ Redox Cycles for Synthesis Gas Production. Energy Technol. 2019, 7, 1800588. [CrossRef]

13. Fuqiang, W.; Ziming, C.; Jianyu, T.; Yuan, Y.; Yong, S.; Linhua, L. Progress in concentrated solar power technology with parabolic trough collector system: A comprehensive review. Renew. Sustain. Energy Rev. 2017, 79, 1314-1328. [CrossRef]

14. Shagdar, E.; Shuai, Y.; Lougou, B.G.; Ganbold, E.; Chinonso, O.P.; Tan, H. Analysis of heat flow diagram of small-scale power generation system: Innovative approaches for improving techno-economic and ecological indices. Sci. China Technol. Sci. 2020, 63, 2256-2274. [CrossRef]

15. Sun, J.; Zhang, Z.; Wang, L.; Zhang, Z.; Wei, J. Comprehensive Review of Line-Focus Concentrating Solar Thermal Technologies: Parabolic Trough Collector (PTC) vs Linear Fresnel Reflector (LFR). J. Therm. Sci. 2020, 29, 1097-1124. [CrossRef]

16. Reddy, V.S.; Kaushik, S.; Tyagi, S. Exergetic analysis and performance evaluation of parabolic trough concentrating solar thermal power plant (PTCSTPP). Energy 2012, 39, 258-273. [CrossRef]

17. Desai, N.B.; Bandyopadhyay, S. Optimization of concentrating solar thermal power plant based on parabolic trough collector. J. Clean. Prod. 2015, 89, 262-271. [CrossRef]

18. Yuanjing, W.; Cheng, Z.; Yanping, Z.; Xiaohong, H. Performance analysis of an improved 30 MW parabolic trough solar thermal power plant. Energy 2020, 213, 118862. [CrossRef]

19. Sultan, A.J.; Hughes, K.J.; Ingham, D.B.; Ma, L.; Pourkashanian, M. Techno-economic competitiveness of 50 MW concentrating solar power plants for electricity generation under Kuwait climatic conditions. Renew. Sustain. Energy Rev. 2020, 134, 110342. [CrossRef]

20. Wang, A.; Han, X.; Liu, M.; Yan, J.; Liu, J. Thermodynamic and economic analyses of a parabolic trough concentrating solar power plant under off-design conditions. Appl. Therm. Eng. 2019, 156, 340-350. [CrossRef]

21. Praveen, R.P.; Awan, A.B.; Zubair, M.; Baseer, M.A. Performance Analysis and Optimization of a Parabolic Trough Solar Power Plant in the Middle East Region. Energies 2018, 11, 741. [CrossRef]

22. Shafiee, M.; Alghamdi, A.; Sansom, C.; Hart, P.; Encinas-Oropesa, A. A Through-Life Cost Analysis Model to Support Investment Decision-Making in Concentrated Solar Power Projects. Energies 2020, 13, 1553. [CrossRef]

23. Boukelia, T.E.; Arslan, O.; Mecibah, M. Potential assessment of a parabolic trough solar thermal power plant considering hourly analysis: ANN-based approach. Renew. Energy 2017, 105, 324-333. [CrossRef]

24. Ikhlef, K.; Larbi, S. Techno-economic optimization for implantation of parabolic trough power plant: Case study of Algeria. J. Renew. Sustain. Energy 2020, 12, 063704. [CrossRef]

25. Teleszewski, T.; Żukowski, M.; Krawczyk, D.; Rodero, A. Analysis of the Applicability of the Parabolic Trough Solar Thermal Power Plants in the Locations with a Temperate Climate. Energies 2021, 14, 3003. [CrossRef] 
26. Aqachmar, Z.; Allouhi, A.; Jamil, A.; Gagouch, B.; Kousksou, T. Parabolic trough solar thermal power plant Noor I in Morocco. Energy 2019, 178, 572-584. [CrossRef]

27. Mohamed, M.H.; El-Sayed, A.Z.; Megalla, K.F.; Elattar, H.F. Modeling and performance study of a parabolic trough solar power plant using molten salt storage tank in Egypt: Effects of plant site location. Energy Syst. 2019, 10, 1043-1070. [CrossRef]

28. Mokheimer, E.M.; Dabwan, Y.N.D.; Habib, M.A.; Said, S.A.; Al-Sulaiman, F.A. Techno-economic performance analysis of parabolic trough collector in Dhahran, Saudi Arabia. Energy Convers. Manag. 2014, 86, 622-633. [CrossRef]

29. Wang, J.; Bi, X. Performance Simulation Comparison for Parabolic Trough Solar Collectors in China. Int. J. Photoenergy 2016, 2016, 9260943. [CrossRef]

30. González-Portillo, L.F.; Muñoz-Antón, J.; Martínez-Val, J.M. An analytical optimization of thermal energy storage for electricity cost reduction in solar thermal electric plants. Appl. Energy 2017, 185, 531-546. [CrossRef]

31. Topel, M.; Laumert, B. Improving concentrating solar power plant performance by increasing steam turbine flexibility at start-up Sol. Energy 2018, 165, 10-18. [CrossRef]

32. Schenk, H.; Dersch, J.; Hirsch, T.; Polklas, T. Transient Simulation of the Power Block in a Parabolic Trough Power Plant. In Proceedings of the 11th International Modelica Conference, Versailles, France, 21-23 September 2015; Volume 118, pp. 605-614.

33. Gonzalez, A.G.; Cabal, J.V.A.; Berrocal, M.A.V.; Menéndez, R.P.; Fernández, A.R. Simulation of a CSP Solar Steam Generator Using Machine Learning. Energies 2021, 14, 3613. [CrossRef]

34. Salazar, G.A.; Fraidenraich, N.; de Oliveira, C.A.A.; de Castro Vilela, O.; Hongn, M.; Gordon, J.M. Analytic modeling of parabolic trough solar thermal power plants. Energy 2017, 138, 1148-1156. [CrossRef]

35. Ezeanya, E.K.; Massiha, G.H.; Simon, W.E.; Raush, J.R.; Chambers, T.L. System advisor model (SAM) simulation modelling of a concentrating solar thermal power plant with comparison to actual performance data. Cogent Eng. 2018, 5, 1-26. [CrossRef]

36. Krishna, Y.; Faizal, M.; Saidur, R.; Manihalla, P.P.; Karinka, S. Performance analysis of Parabolic Trough Collector using TRNSYS ${ }^{\circledR}$ A case study in Indian coastal region. J. Phys. Conf. Ser. 2021, 1921, 012063. [CrossRef]

37. Montañés, R.M.; Windahl, J.; Pålsson, J.; Thern, M. Dynamic Modeling of a Parabolic Trough Solar Thermal Power Plant with Thermal Storage Using Modelica. Heat Transf. Eng. 2018, 39, 277-292. [CrossRef]

38. SimTech Simulation Technology. Operation Manual of Concentrating Solar Power Library; Simtech: Graz, Austria, 2016.

39. Zaversky, F.; Bergmann, S.; Sanz, W. Detailed Modeling of Parabolic Trough Collectors for the Part Load Simulation of Solar Thermal Power Plants. In Proceedings of the ASME Turbo Expo 2012, Kopenhagen, Denmark, 13-15 June 2012 ; pp. 1-13.

40. Perz, E. A Computer Method for Thermal Power Cycle Calculation. In Proceedings of the Gas Turbine and Aeroengine Congress and Exposition, Brussels, Belgium, 11-14 June 1990. [CrossRef]

41. Shuai, Y.; Shagdar, E.; Lougou, B.G.; Mustafa, A.; Doljinsuren, B.; Han, D.; Tan, H. Performance analysis of 200 MW solar coal hybrid power generation system for transitioning to a low carbon energy future. Appl. Therm. Eng. 2021, 183, 116140. [CrossRef]

42. Odeh, S.; Morrison, G.; Behnia, M. Modelling of parabolic trough direct steam generation solar collectors. Sol. Energy 1998, 62, 395-406. [CrossRef]

43. Geyer, M.; Lüpfert, E.; Osuna, R.; Esteban, A.; Schiel, W.; Schweitzer, A.; Zarza, E.; Nava, P.; Langenkamp, J.; Mandelberg, E. Eurotrough-Parabolic Trough Collector Developed for Cost Efficient Solar Power Generation. In Proceedings of the 11th International Symposium on Concentrating Solar Power and Chemical Energy Technologies, Zurich, Switzerland, 4-6 September 2002; pp. 1-7.

44. Krishna, Y.; Faizal, M.; Saidur, R.; Ng, K.C.; Aslfattahi, N. State-of-the-art heat transfer fluids for parabolic trough collector. Int. J. Heat Mass Transf. 2020, 152, 119541. [CrossRef]

45. Li, C.; Yang, Z.; Zhai, R.; Yang, Y.; Patchigolla, K.; Oakey, J.E. Off-design thermodynamic performances of a solar tower aided coal-fired power plant for different solar multiples with thermal energy storage. Energy 2018, 163, 956-968. [CrossRef]

46. Shagdar, E.; Lougou, B.G.; Shuai, Y.; Anees, J.; Damdinsuren, C.; Tan, H. Performance analysis and techno-economic evaluation of $300 \mathrm{MW}$ solar-assisted power generation system in the whole operation conditions. Appl. Energy 2020, 264, 114744. [CrossRef]

47. Montes, M.J.; Abánades, A.; Martínez-Val, J.M.; Valdés, M. Solar multiple optimization for a solar-only thermal power plant, using oil as heat transfer fluid in the parabolic trough collectors. Sol. Energy 2009, 83, 2165-2176. [CrossRef]

48. Munz, B.; Hays, J. Concentrating Solar Trough Modeling: Calculating Efficiency. Tech Briefs 2009, 135, 1-4.

49. Kurup, P.; Turchi, C.S. Parabolic Trough Collector Cost Update for the System Advisor Model (SAM); NREL/TP-6A20-65228; National Renewable Energy Laboratory: Golden, CO, USA, 2015.

50. The World Bank. Direct Normal Irradiation Map of Mongolia. Available online: https://solargis.com/maps-and-gis-data/ download/mongolia (accessed on 17 July 2021).

51. Crawley, D.; Lawrie, L. Development of Global Typical Meteorological Years (TMYx) 2019. Available online: http:/ climate. onebuilding.org/WMO_Region_2_Asia/MNG_Mongolia/index.html (accessed on 17 June 2021).

52. Aalborg CSP. Aalborg CSP Steam Generators; Technical Report; Aalborg CSP: Aalborg, Denmark, 2011. Available online: https://www.aalborgcsp.com/fileadmin/user_upload/beUid/1/1-Downloadable_materials/1-Brochures/2011_09_01__ Brochure_SGS_technical.pdf.

53. Llamas, J.M.; Bullejos, D.; de Adana, M.R. Techno-Economic Assessment of Heat Transfer Fluid Buffering for Thermal Energy Storage in the Solar Field of Parabolic Trough Solar Thermal Power Plants. Energies 2017, 10, 1123. [CrossRef] 
54. Shagdar, E.; Shuai, Y.; Lougou, B.G.; Mustafa, A.; Choidorj, D.; Tan, H. New integration mechanism of solar energy into 300 MW coal-fired power plant: Performance and techno-economic analysis. Energy 2021, 238, 122005. [CrossRef]

55. Chen, H.; Xue, K.; Wu, Y.; Xu, G.; Jin, X.; Liu, W. Thermodynamic and economic analyses of a solar-aided biomass-fired combined heat and power system. Energy 2021, 214, 119023. [CrossRef] 